DOI: $10.23858 / S A 70.2018 .014$

\author{
Kamil Niedziółka*, Paweł Szczepanik**, Mikołaj Lisowski****
}

\title{
A UNIQUE FIND OF A SILVER CROSS-SHAPED EARRING FROM AN EARLY MEDIEVAL SETTLEMENT AT SZEMUD, SITE 4, IN EASTERN POMERANIA, POLAND
}

\begin{abstract}
Niedziółka K., Szczepanik P. and Lisowski M. 2018. A unique find of a silver cross-shaped earring from an early medieval settlement at Szemud, site 4, in Eastern Pomerania, Poland. Sprawozdania Archeologiczne 70, 297325 .

This paper presents the results of an analysis of archaeological material recovered in 2014 during the rescue excavations at site 4 in the Szemud locality, in the Eastern Pomerania region of Poland. The investigations revealed a small fragment of an open settlement from the early medieval period with especially interesting materials. Besides a large amount of pottery dating the site to the eleventh century, a collection of metal artefacts was discovered. The most interesting find was a cross-shaped earring made of silver. This find is unique; so far, artefacts of this type have only been discovered as parts of hoards. The findings indicate that the site was unusual in its character, and is particularly interesting considering the unsatisfactory state of research on early medieval settlement in this area.
\end{abstract}

Keywords: settlement; early medieval period; Eastern Pomerania; cross-shaped earring; pottery Received: 28.02.2018; Revised: 18.04.2018; Accepted: 20.09.2018

* Institute of Archaeology, Cardinal Stefan Wyszyński University, Warsaw, Poland; k.niedziolka@wp.pl

** Institute of Archaeology, Nicolaus Copernicus University, Toruń, Poland;pawelszczepanik@umk.pl

*** Department of Archaeology, University of Sheffield, UK; mikolaj.lisowski@gmail.com 


\section{INTRODUCTION}

In June 2014, in advance of the development of local sport infrastructure, an archaeological rescue excavation was carried out at Szemud (Szemud commune, Wejherowo district, Fig. 1a) in Eastern Pomerania - a region in the northern Poland also known as Gdańsk Pomerania. Two trenches were opened at the site, yielding numerous archaeological findings. The excavations in Trench I (Fig. 1b), located in the southern part of the study area, revealed several dozen features associated with a cist-stone grave cemetery of the so-called Pomeranian culture, dated to phases $\mathrm{C}$ and $\mathrm{D}$ of the Hallstatt period. The sandy elevation on which the cemetery was located, north-west of the present-day centre of Szemud, was also investigated by Polish archaeologists before World War II. At that time, two separate but adjacent locations with groupings of the cist-stone graves were distinguished (Dobrogowski 1949, 299-314); however, in light of subsequent post-war discoveries (Szymańska 1968, 371-372, Pietrzak 1977, 505-507), as well as those from 2014, it is more probable that these graves are a part of one large cemetery from the early Iron Age. Archaeological material from that period is, however, the subject of a separate study (Niedziółka and Jasińska 2017, 105-138).

This paper focuses on features from Trench II, located in the northern part of the study area (Fig. 1b, 2). Excavations in this trench unearthed remnants of a previously unknown early medieval settlement from the eleventh century. These findings, although relatively few (see below), are very interesting from the academic point of view. It seems that they can make a significant contribution to the research on the early medieval settlements in Eastern Pomerania.

\section{CHARACTERISTICS OF THE NATURAL ENVIRONMENT}

According to the geographic taxonomy developed by J. Kondracki, Szemud is located in the northern part of the Kashubian Lake District mesoregion (Kondracki 2002, 74-48). In an even more detailed view, J. Gacki and J. Szukalski (1979, 240-241) described this area as a borderland of an almost entirely wooded sub-mesoregion of the GniewowoKoleczkowo Upland - located to the south of the present-day town of Wejherowo, and to the west of the town of Rumia - and the Łebno-Kielno Moraine Sub-mesoregion, located to the west of the present-day city of Gdynia. Interestingly, in light of the latest systematics made for the Kashubian Lake District itself, based on older divisions verified with GIS tools, the Szemud region can be also divided as a separate micro-region defined as the Szemud Upland (Kistowski and Szydłowski 2015, 173, Fig. 6). This indicates the existence of a geographical distinctiveness of this area.

Prehistoric settlement in this area has two main characteristics: the preference for lesssloping areas; and zones in the vicinity of watercourses or lakes (Kittel 2005, 90-91). Site 

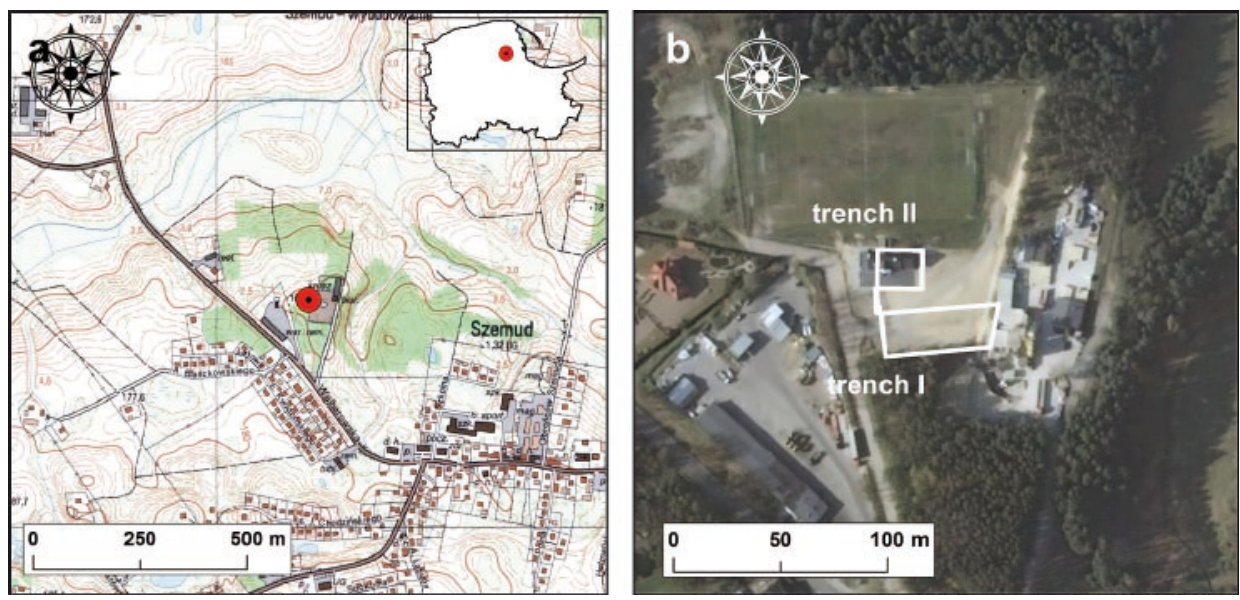

Fig. 1. a - location of site 4 at Szemud on the topographic map of the nearest area; b - excavation season 2014 - orthophotomap with the location of trenches I and II together with a trial trench between them (author: K. Niedziółka, source of the background maps: http://www.geoportal.gov.pl/)

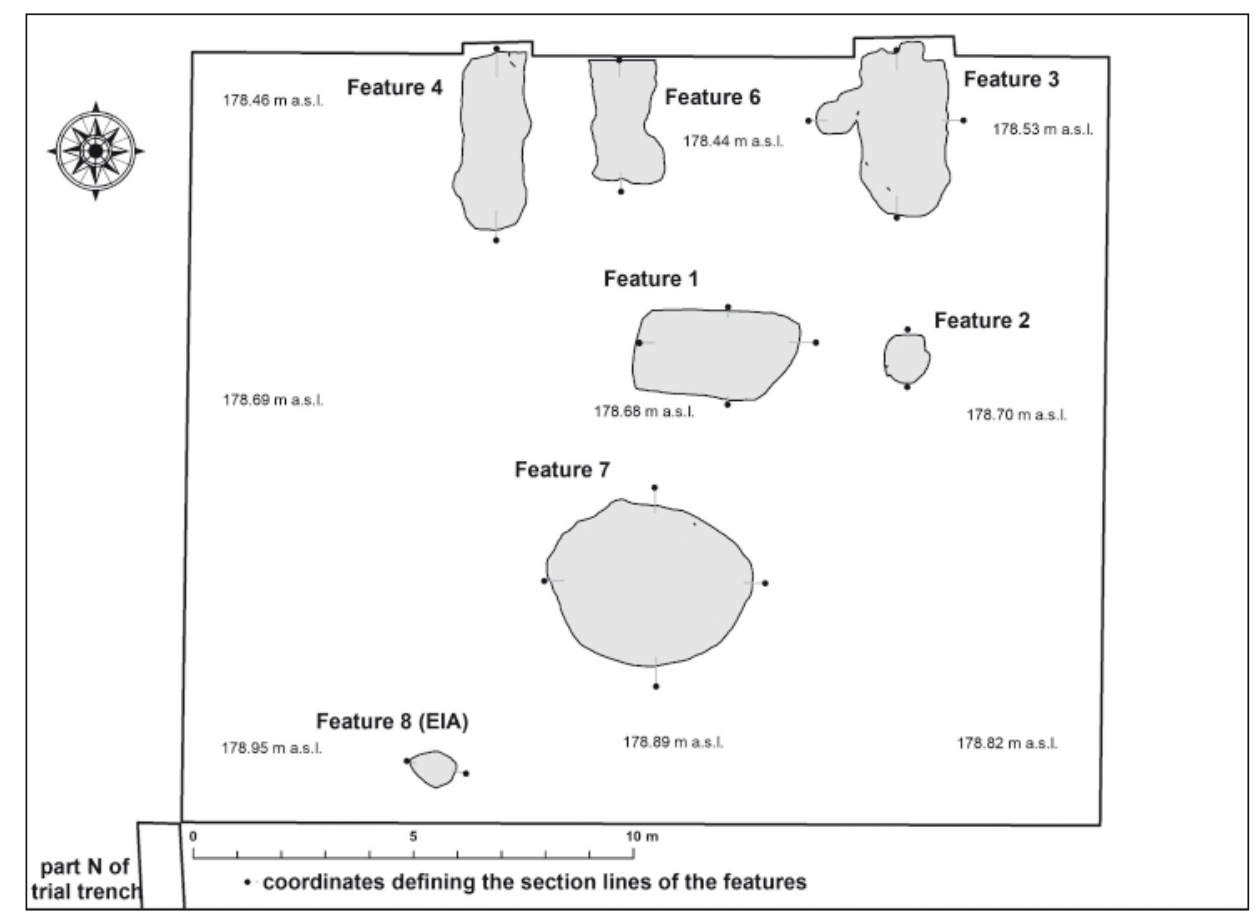

Fig. 2. Distribution of features in trench II (author: K. Niedziółka) 
a

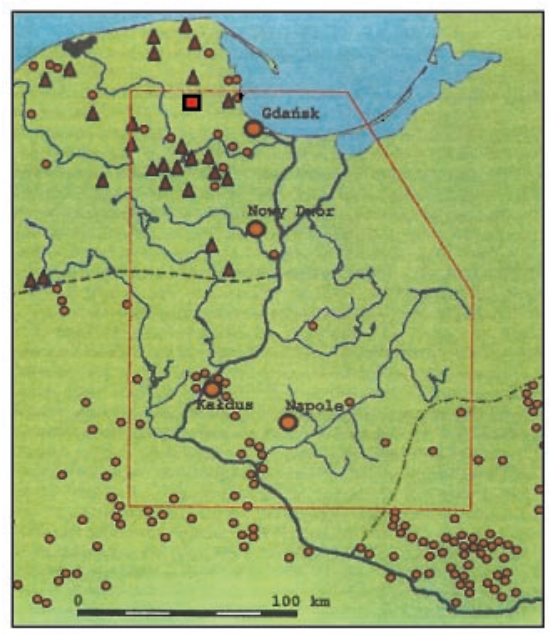

b

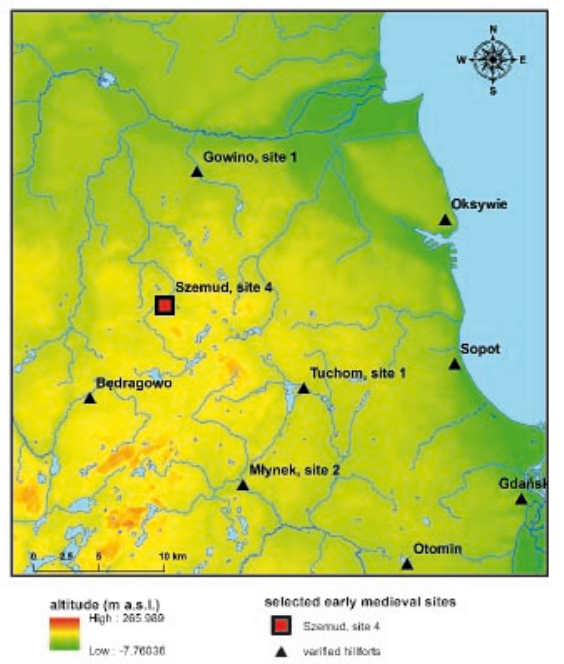

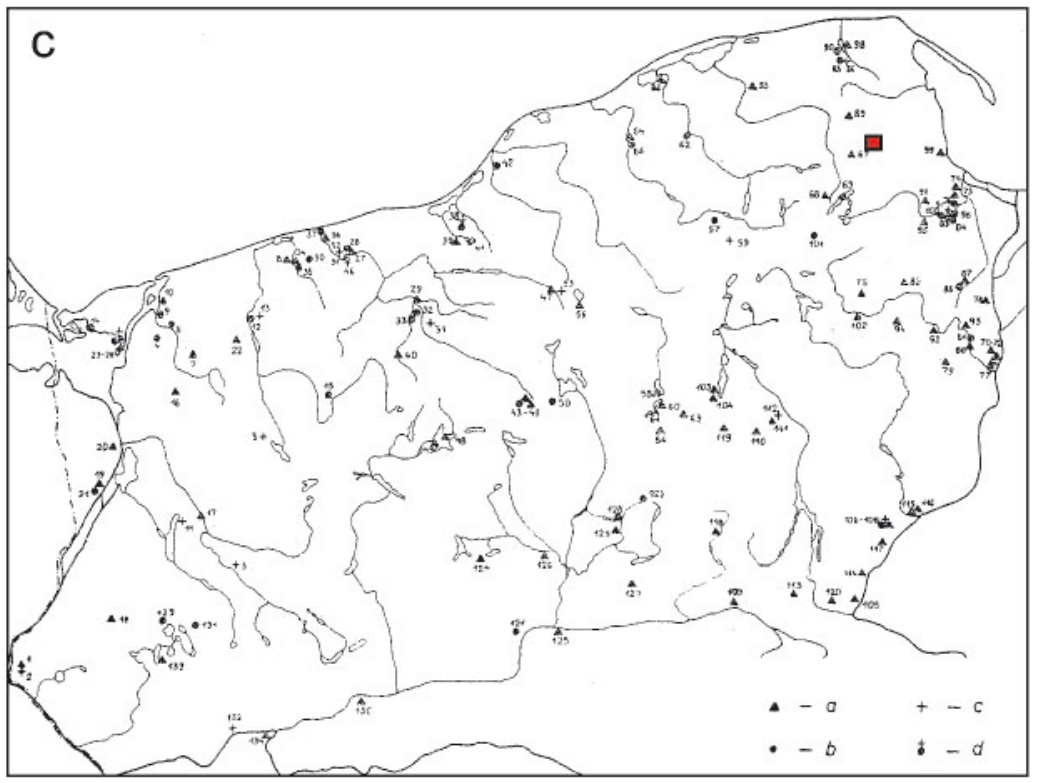

Fig. 3. a - map of the location of early medieval cemeteries (triangle - barrow cemeteries, circle - flat cemeteries) excavated in years 1987-2003, site 4 at Szemud marked as a square (after: Chudziak 2006, 179, Ryc. 2 with modifications); b - locations of verified early medieval hillforts (triangles) in the immediate vicinity of site 4 at Szemud (square) (author: K. Niedziółka, data taken from: Ostasz 2014, 58, ryc. 1, 83); c - map of Pomeranian early medieval sites excavated in years 1945-1977 (a - hillforts and urban sites; b - settlements and alleged settlements; $c$ - cemeteries; $d$ - alleged places of pagan worship; site 4 at Szemud marked as a square; after: Łosiński 1981, 135, ryc. 1 with modifications) 

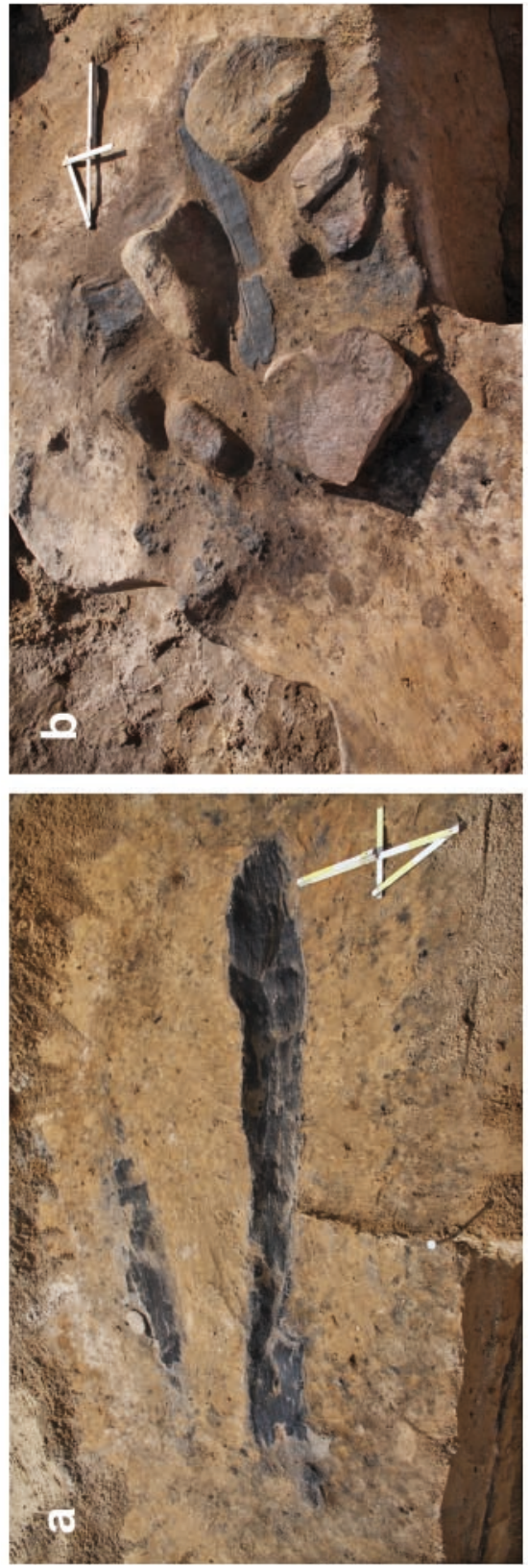
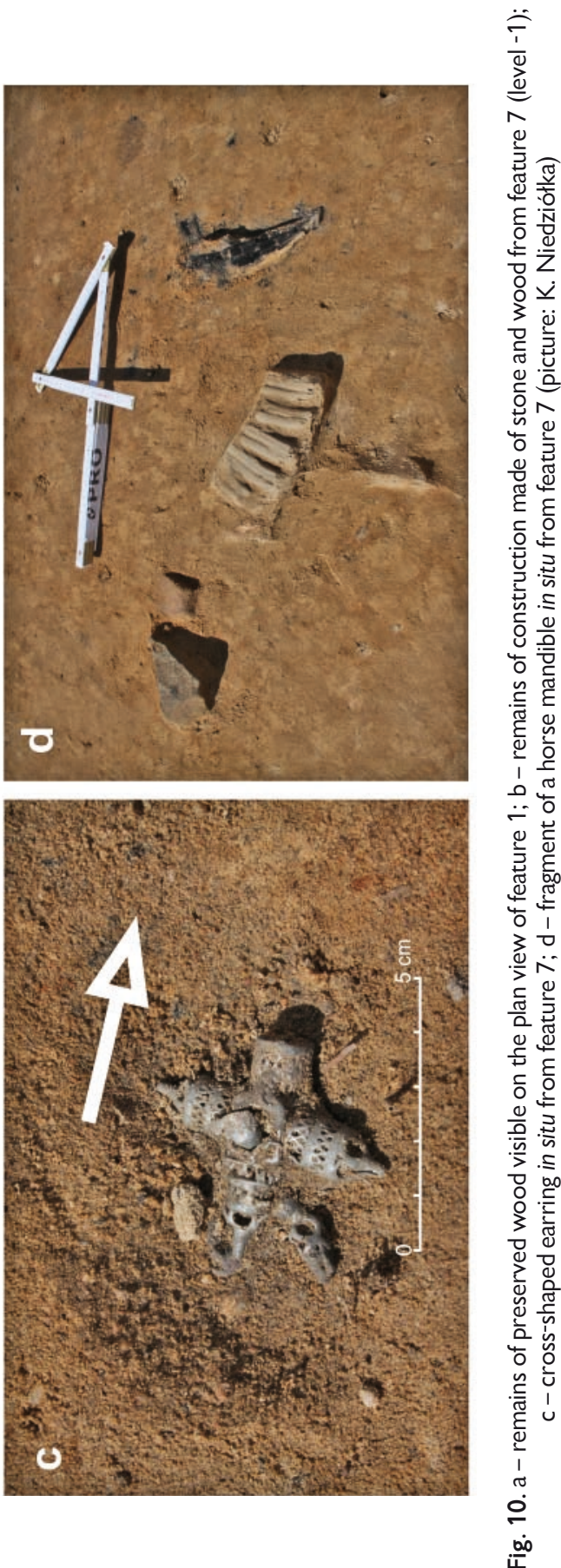


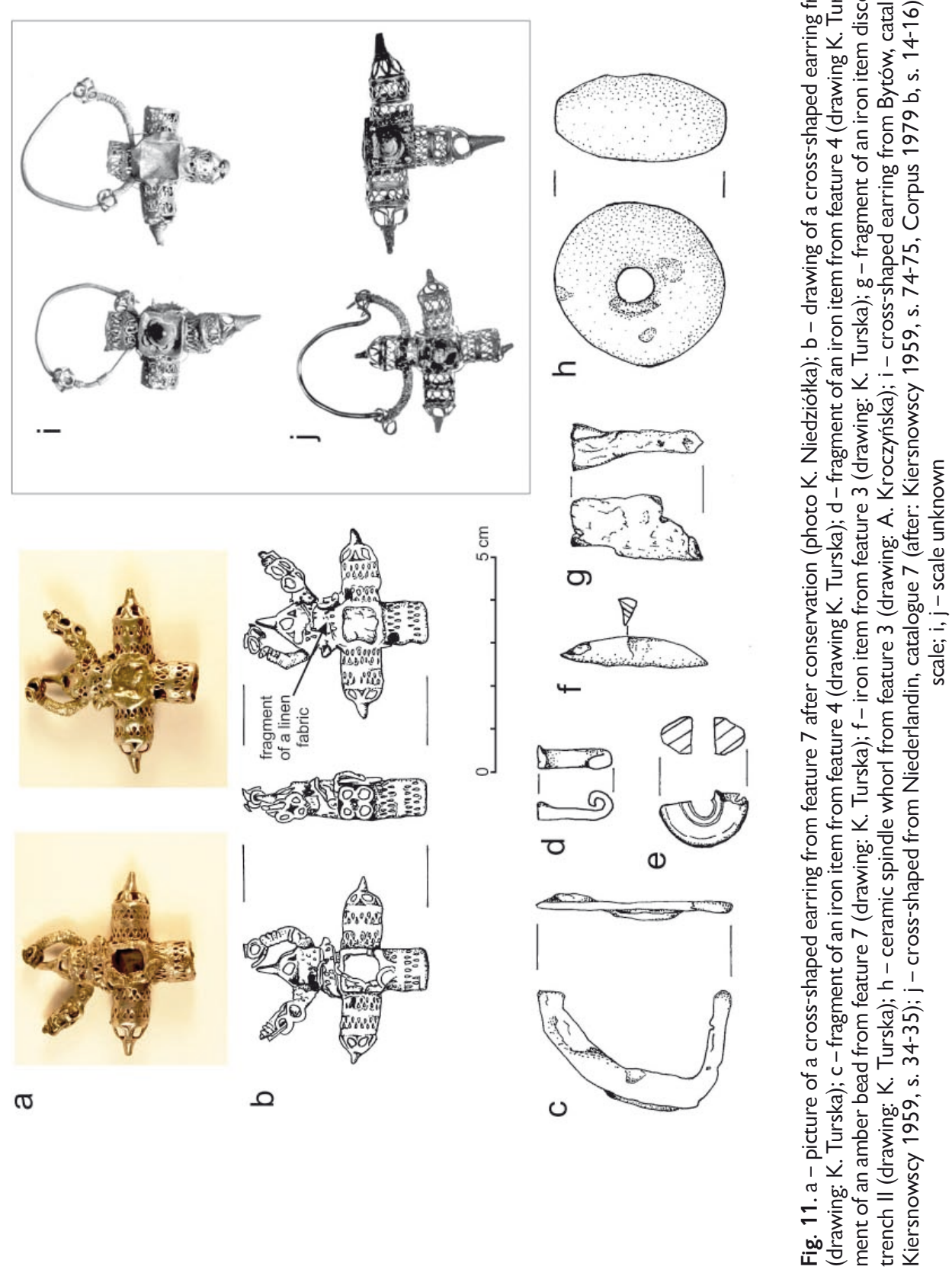


4 shares the same characteristics, therefore these observations may also hold true for the early medieval settlement. As it was mentioned in the introduction, the site is located on a gentle slope of a sandy hill, and in a quite close distance from it (ca. 420-430 metres) there is the modern bed of the Gościcina River (Fig. 1a). The river valley is quite well defined in this area and is restricting the course of the Gościcina, which has probably not changed much in the last several hundred years.

In terms of geomorphological forms, according to current cartographic approaches (see: Ochtyra 2012; Marcinkowska et al. 2013, 43-79), the settlement at Szemud is located within a (curved) moraine plateau formed during the Baltic glaciation. It is usually characterised by small and irregular elevations and depressions, although in the case of the study area the elevation difference between the exact location of the settlement at Szemud and the bottom of the nearby Gościcina River valley oscillate around as much as 20-25 metres. This type of landscape is considered typical for this part of Eastern Pomerania.

In addition to the topographic analysis of the immediate natural environment of site 4 at Szemud, it is also worth examining the so-called potential natural vegetation (Matuszkiewicz 2008). To some extent, this can be helpful in reconstructing the past natural conditions of the study area in the context of archaeological settlement research (Kruk, Przywara 1983, 19-23). The very concept of potential natural vegetation can be defined as a hypothetical state of the vegetation complexes that would develop in the case of the complete cessation of the human activity in the investigated area (Matuszkiewicz 2008). Therefore, it is not an ideal reproduction of the vegetation shape that existed in the past that is primeval vegetation - but it is certainly much closer to it compared to the modern state. Based on the current study by J. M. Matuszkiewicz (2008), it can be concluded that the settlement at Szemud was located on the border of three different vegetation complexes: lowland riparian ash-alder forest (Fraxino-Alnetum (=Circaeo-Alnetum), poor lowland beech forest (Luzulo pilosae-Fagetum) and the acidophilic Pomeranian beechoak forest (Fago-Quercetum petraeae). As for the first complex, it is characteristic for the wide valleys of smaller rivers (Matuszkiewicz 1993, 38). Its occurrence can be probably associated with the presence of the nearby Gościcina River valley. In the case of low beech forest complexes (Matuszkiewicz 1993, 32), they occur in small surface and low-fertility vegetation zones characteristic of Eastern Pomerania. They grow mainly on elevations and steep slopes of hills and valleys. The latter complex, that is the acidophilic Pomeranian beech-oak forest, as its name suggests, occurs only in Pomerania and is identified with sand-gravel areas associated with moraine uplands, as well as with outwash plains or Pleistocene river terraces (Matuszkiewicz 1993, 33). Based on this brief description, it can be concluded that the settlement at Szemud was located within the vegetation zone of a rather strong regional character, typical for the region of Pomerania, particularly its eastern part.

The concluding part of this section discusses the properties of the local soil cover. Based on the digital data concerning soil types and their contemporary agricultural suita- 
bility taken from the Provincial Centre for Geodesic and Cartographic Documentation in Gdańsk [Polish acronym WODGiK], it is possible to determine the quality of the soil in the immediate vicinity of the studied settlement. Regarding the type of soil on which this site was located, according to Polish soil definitions from 1989 (see: Bielska et al. 2014, 167175) together with the World Reference Base for soil resources from 2006 (WRB 2006), this region is characterised by a clear dominance of a subtype of brown leached soil (type: Haplic Cambisol), which is a dominant subtype of soil in the whole of Eastern Pomerania. Concerning the quality of these soils, they can be described as medium-fertile; however, this is not always the case (Pelisiak and Gębica 2007, 108). In the immediate vicinity of the investigated site, specifically in the area at the bottom of the Gościcina valley, alluvial soils (fluvisol) are present. These soils - typical for lower, often boggy, parts of river valleys are characterised by diversified fertility, but often are a desirable basis for plant and animal husbandry, also in prehistory and early-historical periods (Pelisiak and Gębica 2007, 112-113). Therefore, it is plausible that this area was used intensively by the early medieval inhabitants, provided the water table was not too shallow. The presented observations are, in general, very similar to the modern complexes of soil agricultural usefulness. This site is located directly on soils described as the so-called weakest rye complex, which indicates a low usefulness from the perspective of the modern agricultural economy (Pelisiak and Gębica 2007, 116). On the other hand, the direct area of the settlement did not necessarily have to be used for farming, given that in a slightly larger distance (a radius of 500-600 metres) soils have better quality; for example, so-called weak rye, good rye, or even very good rye complexes. What is more, extensive parts of the studied area have the characteristics of grasslands, including those of the best quality. This indicates, therefore, the existence of potentially good, or even very good, conditions for the possible grazing of livestock. To sum up, the soil cover in the immediate vicinity of the studied settlement was generally of medium quality, although there was no shortage of soil of a clearly more fertile character. This area had potential for both plant and animal husbandry. However, it must be clearly stated, that these soils characteristics are based on completely contemporary conditions and standards, which only to a certain extent, virtually impossible to define at present, may correspond to the situation that prevailed during the early Middle Ages. It is obvious that soil properties undergo constant changes under the influence of both natural and anthropogenic factors (Pelisiak and Gębica 2007, 117-119). For this reason, all the remarks presented in this paragraph should be approached with caution and treated rather as an approximate characteristic in terms of the probable economic potential in the past.

To sum up this section, the natural environment around the settlement at Szemud can be described as quite typical for the eastern part of Pomerania. The local natural resources seemed to be rather moderate. The close presence of the Gościcina River probably influenced the location of this settlement; however, this is hardly a surprising conclusion. It is difficult to inquire, on the basis of contemporary data, into the type of economy of the early medieval inhabitants of this settlement. 


\section{THE SETTLEMENT AT SZEMUD IN THE CONTEXT OF THE LOCAL EARLY MEDIEVAL SETTLEMENT}

The early medieval settlement situation within the northern part of Eastern Pomerania may be very difficult to assess due to the highly unsatisfactory state of archaeological recognition of this area. This statement appeared in many studies of this part of Pomerania over the course of many years (e.g. Choińska 1975, 151-189; Łosiński 1981, 131-151; Chudziak 2006, 176-177), and, according to W. Chudziak (2006, 176-177), this situation have hardly changed since the 1970 . Hitherto, more attention has been devoted to the archaeology of the area of Vistula estuary, also called Pomorze Nadwiślańskie (Choińska 1975, 151-189; Chudziak 2006, 175-187), which is located in the southern part of Eastern Pomerania. Its northern part - covering a part of the Kashubian Lake District together with Kashubian Seacoast, Glacial Valley of rivers Reda-Łeba, and Żarnowiec Upland - on the other hand, is less recognised. In addition, a large part of the material stored in museums has not been published so far, presumably including the latest verification studies carried out on the local hillforts (Ostasz 2014, 59).

In recent years, however, there has been some increase of the available information, primarily in the form of publications of findings from open settlements discovered during large-scale rescue excavations in advance to road investments. Notable examples include Juszkowo-Rusocin, district Gdańsk, site 28 (Bednarczyk 2003, 196-197); Malenin, district Tczew, site 5 (Adamska 2005, 171-180); Janków Gdański, district Gdańsk, site 14 (Nierychlewska 2013, 271-291); and Ulkowy, district Gdańsk, site 24 (AUT) (Fudziński et al. 2007, 72-73). Those findings are particularly important for the current investigation because the site at Szemud was also an open settlement in a rural context, which is not necessarily self-evident for the early Middle Ages (see: Poklewski 1992, 297-298). Unfortunately, in comparison to the state of research on the local hillforts, the issue of open settlements is also heavily neglected. The last summative publication referring to the early Middle Ages in Pomerania (see: Paner et al. 2014) brought very little change in this matter.

Unfortunately, the surroundings of the studied settlement also suffer from a very poor reconnaissance under the Polish Archaeological Record programme (Polish abbreviation: AZP), whose main aim is to list all known archaeological sites in Poland. In the case of the Pomeranian Voivodship, this programme was hitherto implemented only for 70 percent of the area (Niedziółka 2016, 135). For the investigated region, out of nine sheets (areas) closest to the site at Szemud, only five are complete (numbers 08-41, 09-39, 09-41, 10-40 and 1041). The remaining four (numbers 08-39, 08-40, 09-40, 10-39), including the one with site number 4 (sheet number 09-40), are considered "empty" areas of the AZP. Nonetheless, based on the previously mentioned five complete sheets, it can be inferred that there was no substantial increase in the number of finds dated to the early medieval period in the areas they represent. On the other hand, of course, AZP is largely based on ground surveys which yield a limited number of usually badly preserved material and whose dating may be 
very ambiguous and needs to be treated with caution. AZP is also primarily a conservation programme, not a strictly scientific one.

The abovementioned problems make it impossible to present here a comprehensive analysis of the settlement situation in the immediate surroundings of the settlement at Szemud. Based on the previous remarks, only the most basic conclusions can be made. Both in the context of the early medieval cemeteries (Fig. 3a, c) and previously excavated hillforts (Fig. 3b), it can be noticed that this site is located outside the concentrations of contemporary cemeteries, as well as at a significant distance from the well-dated hillforts. Having this in mind, it can be carefully suggested that this settlement was probably not a part of a larger settlement concentration, but rather a part of a more scattered settlement network from that period. To a certain extent, this may be supported by the analysis of the natural environment of the immediate surroundings from the previous part of this paper which did not recognise the distinct attractiveness of this area compared to other regions of Eastern Pomerania. On the other hand, one should bear in mind that the current archaeological reconnaissance of a given area cannot be directly corresponded to the settlement situation existing in the past. The former is a result of many, often quite modern factors - such as the intensity of earthworks, location of large investments, and the presence of research programmes targeted at the area, to name but a few of them.

Another issue concerns the chronological framework for the site at Szemud and recognising other local early medieval sites of the corresponding dating. The discussed site is very unique and constitutes a precedent among similar sites due to its very precise dating; rarely possible to be determined on other settlements, early medieval or other. This results in a situation where a reliable map of settlement sites of a narrow chronological framework cannot be created. What remains, however, is to map the sites of a broader chronological frame.

To sum up, this preliminary investigation of the settlement situation in the region in the vicinity of site 4 at Szemud does not indicate any special significance of this area. The presented maps do not show the existence of any clearly emerging settlement clusters in the area.

\section{THE ARCHAEOLOGICAL FEATURES}

Within Trench II (dimensions: 20 x 18 metres) a total number of eight archaeological features were revealed under the layer of topsoil; seven of them are dated to the early Middle Ages. The following section discusses their analysis in a more detailed way, while feature 8 was linked with Pomeranian Culture and will not be examined here.

Feature 1 (dimensions 375 × 200 x $40 \mathrm{~cm}$, Fig. 4) was found directly under the layer of topsoil, and had the shape of an elongated trapezoid, close to a rectangle. Its floor as well as the main fill consisted of brownish/greyish yellow sand with burnt inclusions and singular fragments of daub. Burnt pine wood (Pinus sylvestris) in the form of two beams or 


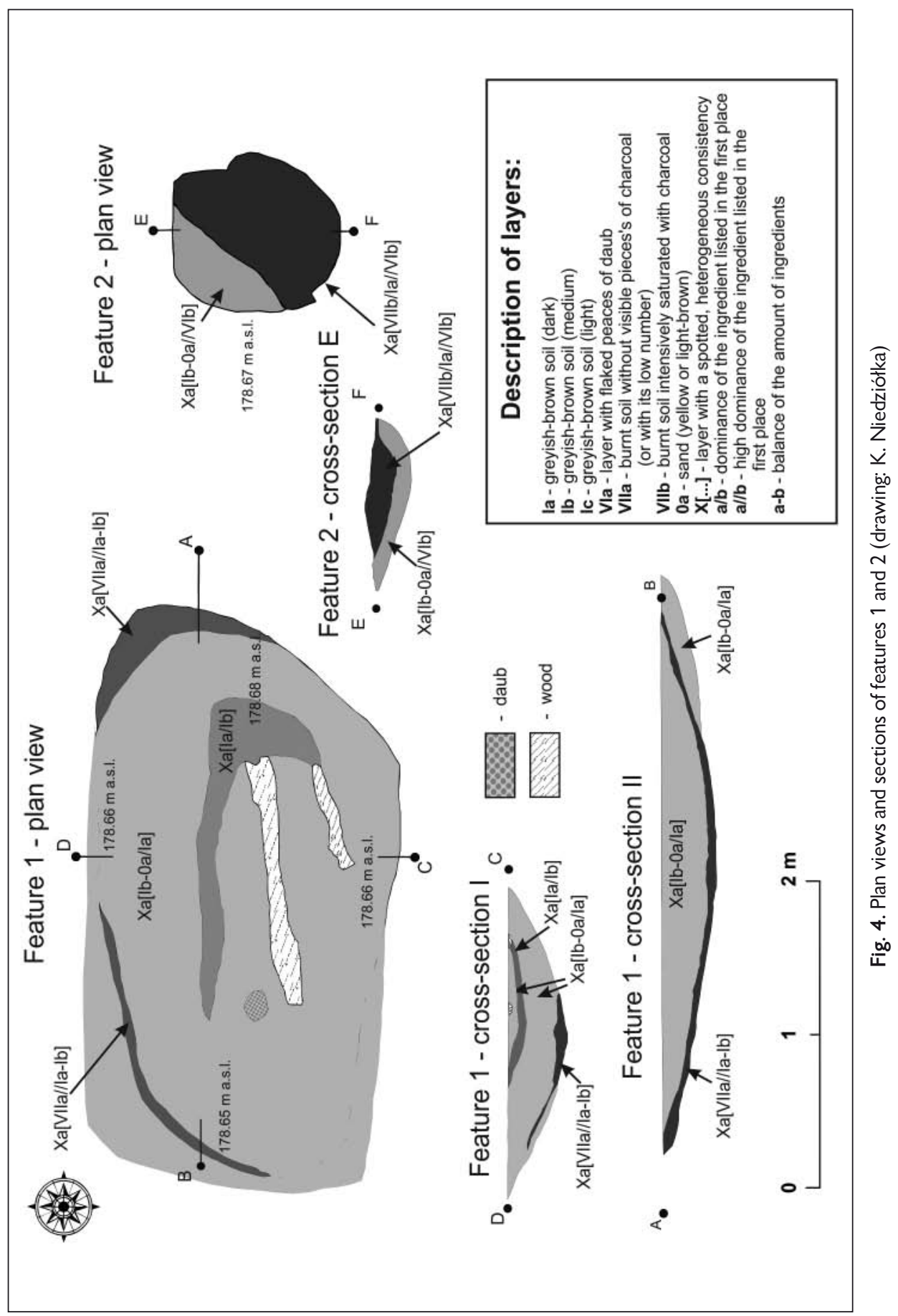




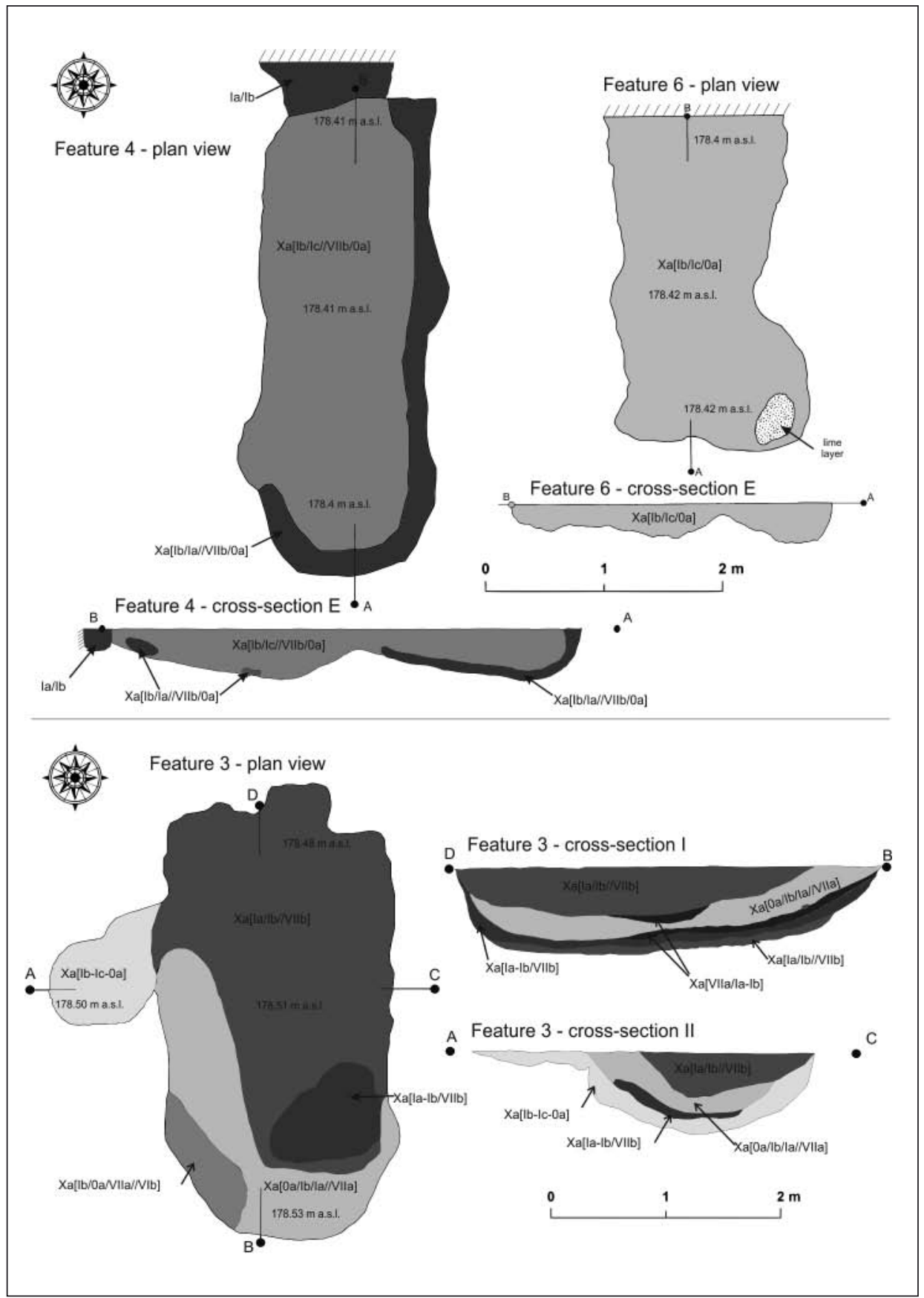

Fig. 5. Plan views and sections of features 3, 4 and 5 (drawing: K. Niedziółka) 
boards was recorded on the first level of exploration (Fig. 10: a). Feature 1, with the area of approximately $7-8 \mathrm{~m}^{2}$, presumably constitutes a remnant of a pit-house. The functional interpretation of the feature will be discussed below.

Feature 2 (dimensions 120 x 104 x $26 \mathrm{~cm}$, Fig. 4) had an oval shape. Its fill consisted of a layer of humus mixed with burned soil and singular fragments of daub. Its second layer was formed by greyish yellow loose sand.

Feature 3 (dimensions 390 x 200 x $70 \mathrm{~cm}$, Fig. 5) had the shape of an irregular rectangle, and its multilayer fill was primarily comprised of burnt soil. What is more, in the southern part of the feature, traces of fire and small stones - both in the topmost layers were discovered. This should be interpreted as an internal fireplace. In addition, in the north-western part of the feature, a round layer of light greyish yellow sand was recorded. This might be a remnant of a much wider layer present originally inside this feature; unfortunately, it was destroyed due to its modest thickness. Its function is, however, difficult to determine.

Feature 4 (dimensions $408 \times 165 \times 36 \mathrm{~cm}$, Fig. 5) had the shape of an elongated, irregular rectangle; double-hollow-shaped in its section. Its fill consisted of brownish grey soil with numerous traces of burning and pieces of charcoal: including fragments of oak (Quercus sp.) and pine (Pinus sylvestris). In addition, the southern and eastern edge of this alleged building was probably reinforced with a layer of daub. In the northern part, feature 4 was partially destroyed by a younger truncation extending beyond the area of excavations. The exact relation between feature 4 and this truncation is difficult to determine because of the lack of finds in the latter one.

Feature 6 (dimensions: 280 x 150 x $34 \mathrm{~cm}$, Fig. 5) had the shape of an elongated, irregular rectangle; its section had a double-hollow shape. The feature's fill consisted of a layer of brownish yellow sand. In its south-eastern part a small oval-shaped layer of lime was discovered. The northern part of feature 4 extended beyond the research area, making it impossible to properly determine its size and function.

Feature 7 (dimensions 466 x 338 x $100 \mathrm{~cm}$, Fig. 6) had an oval shape. Directly under the layer of topsoil it appeared as a homogenous layer of brown sand. The section of this feature had a trapezoidal shape with a flat base. In the central part of the feature, with a slight shift to the east, a construction made of stones, with a diameter of up to $40 \mathrm{~cm}$, was recorded. Inside this construction numerous fragments of burnt oak (Quercus sp.) were revealed. Additionally, a fireplace (Fig. 10: b) was located on the border of two utility layers: the first one described above as brown sand, and the other one consisting of mixed yellowish brown sand.

Trying to undertake the functional analysis of features unearthed at the site, one should bear in mind the given constraints: the limited area of excavation, severely destroyed top parts of the features, and the lack of a cultural layer accumulated when the settlement was inhabited. Feature 1 (Fig. 4) might be interpreted as a remnant of a pit-house (Chudziak 1987, 343; Dulinicz 2001, 120). This structure probably had two phases of utilisation: the 


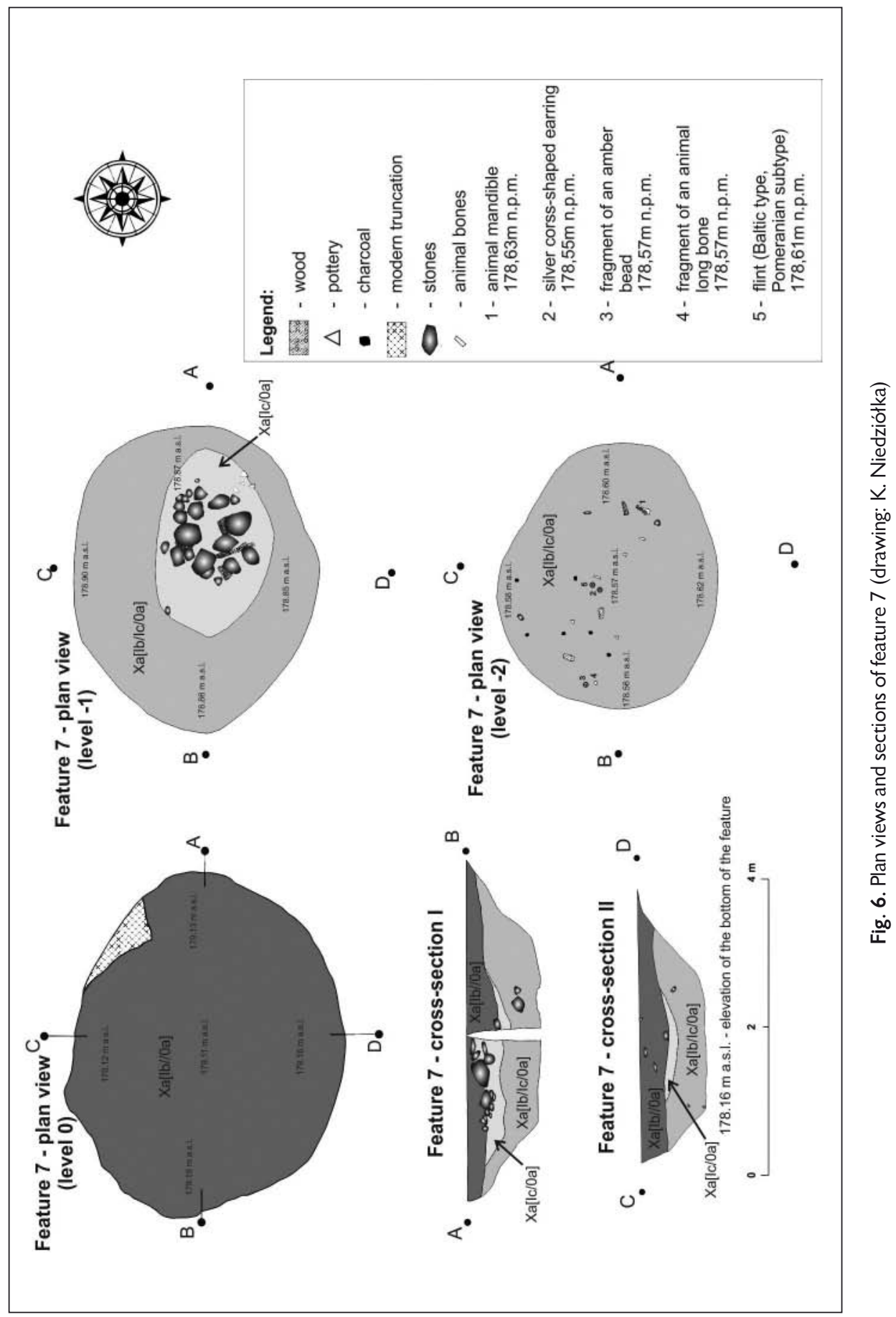


first one marked by the accumulation of the layer of burnt soil at the bottom of the building, and the second one is associated with the burnt pine boards, which can be considered as the remains of wooden flooring (?). It is difficult to determine the technique in which the walls of the building were erected. In the archaeological literature there is a conviction that these kinds of buildings might have been erected using log or wattle construction (Brzostowicz 2014, 74-75). The latter seems to be more possible in the case of feature 1 due to the presence of numerous fragments of daub with traces of organic materials. It is worth considering the purpose of this building and the basic question: can we interpret it as a residential building? In the current literature there is a common belief that residential buildings would need to have a heating device in the form of a fireplace or oven (Dulinicz 2001, 121). In this case, feature 2 should be interpreted as a fireplace, located only about $180 \mathrm{~cm}$ to the east of feature 1 (Fig. 4). It is possible that these two features were the remnants of one residential building with a fireplace/oven. This hypothetical building would presumably be rectangular with an area of about $15 \mathrm{~m}^{2}$, with a small basement under the wooden floor (feature 1) and an oval heating device in the eastern part (feature 2).

A similar interpretation seems to be possible for features 4 and 6 (Fig. 5). These two features, parallel to each other, with similarly double-hollow-shaped sections, might have been originally connected by a thin layer that was destroyed (see: Kobyliński 1988, 102114). In this case, these would be two longitudinal hollows within one pit-house with an estimated area of about $19 \mathrm{~m}^{2}$ (see Chudziak 1988, 187). Assuming this, feature 4 should be interpreted as a remnant of the fireplace (northern part of the structure) connected directly to the pit (southern part). Feature 6 is more difficult to interpret due to the lack of archaeological material discovered. Assuming it was contemporary to feature 4, it could be described as an undefined pit (Dulinicz 2001, 121-122). Of course, there is also an alternative explanation for those two features: the remains of separate buildings/objects with an undefined function. Due to the lack of dated material, it also cannot be ruled out that feature 6 was actually a relic from the beginning of the Iron Age, although such an interpretation seems unlikely.

Feature 3 is yet another plausible remnant of a building (Fig. 5); it is located parallel to and at the same height as features 4 and 6 . This feature has presumed area of up to $12 \mathrm{~m}^{2}$; the western part of the feature seems to have been destroyed due to its small thickness. The feature seems to be an example of a rectangular pit-house with a heating device in the form of a fireplace in the south-eastern part. Presumably, the structure had two phases of use, indicated by the nature of the fill. The first phase of use was represented primarily by the flooring with a strong occurrence of burnt soil, which was subsequently levelled with a layer of yellow sand - serving as the foundation for the second phase of use.

Possibly the most interesting finding at the site, due to its unusual character and recovered artefacts, was feature 7 (Fig. 6) Unlike the abovementioned residential buildings of an elongated shape, in this case we are dealing with an oval form with an area of almost $16 \mathrm{~m}^{2}$. The analysis of the feature's stratigraphy revealed that under the level of wooden floor, 
preserved as burnt oak boards, there was a basement approximately $50 \mathrm{~cm}$ deep with sloping walls and a flat basis. In addition, on the floor level there was a solid hearth, possibly encased in a wooden crate. The collection of artefacts discovered in this feature is particularly interesting and will be discussed in the following section.

\section{FINDS}

\section{Pottery}

Fragmented vessel pottery constituted the most numerous group of artefacts recovered from the settlement at Szemud. Its quantitative and qualitative analyses were based on a descriptive scheme developed for the early medieval ceramics for the purposes of the Adalbertus programme (Chudziak et al. 1997). Simultaneously, the principles of formal classification developed for the material from Szczecin were implemented (Łosiński and Rogosz 1983). The morphological and formal analysis included 311 fragments of varying degrees of preservation and size. An additional 85 fragments were used to reconstruct the forms of four separate vessels from feature 7 ; hence, they were not included in the quantitative analysis (Fig. 7a-d).

Within feature 7, a set of 255 fragments was discovered and subjected to quantitative and qualitative analyses. The largest portion of the assemblage consists of 234 sherds of early medieval pottery. The prehistoric (early Iron Age) pottery was also recorded: 20 sherds; and one sherd was late medieval or modern. Among the early medieval assemblage there were 161 body sherds, 32 rim sherds, and 26 base sherds. In terms of technology, 223 sherds were parts of vessels manufactured with the use of the total cove technique (i.e. completely wheel-finished; technological group V). The technological group second in number of sherds, eight fragments, included vessels with the part of the body below the vessel's maximum girth partially wheel-finished (technological group III).

The analysis of ceramic vessel forms should begin by determining the types of vessels whose entire forms have been reconstructed. This group comprises two vessels (Fig. 7: a, c) of type $J$ according to the classification of pottery from Szczecin (Łosiński and Rogosz 1983, 215), or type Teterow in the classification of pottery from Mecklenburg (Schuldt 1956), dated from the eleventh to the mid-twelfth century AD (Łosiński and Rogosz 1986, 56). Vessels of this type recovered from feature $7 \mathrm{had}$ a well-defined neck, decorated with horizontal notches on almost the whole surface of the reconstructed pot, from the very rim (Fig. 7a) or the middle of the neck downwards (Fig. 7c). The place where the neck was connected to the body was additionally engraved with a single corrugated line accompanied by imprints of a three-tooth tool. The diameter of the first vessel (Figure 7a) is $16.5 \mathrm{~cm}$ and height $15 \mathrm{~cm}$, and the diameter of the second vessel (Figure 7c) is $20 \mathrm{~cm}$, with a reconstructed height of about $19 \mathrm{~cm}$. The $J$ group also includes four other sherds from feature 7 . 
Another reconstructed vessel (Fig. 7d) corresponds to type $\mathrm{G}$ according to the classification of pottery from Szczecin (Łosiński and Rogosz 1983, 212-213) or type Vipperow in the classification of pottery from Mecklenburg (Schuldt 1956). Currently, this type of pottery is dated from the second half of the tenth to the first half of the twelfth century $\mathrm{AD}$ (Błędowski and Chudziak 2014, 127). The vessel discovered in feature 7 is a flagon-shaped form with a diameter of $17 \mathrm{~cm}$ and height of $13.6 \mathrm{~cm}$. It was decorated with three rows of

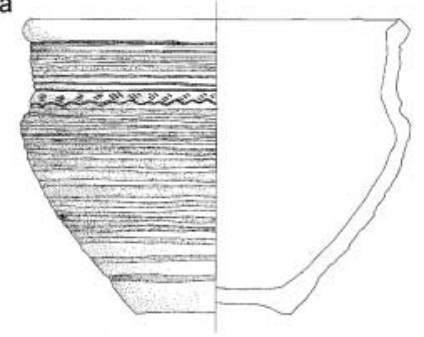

C

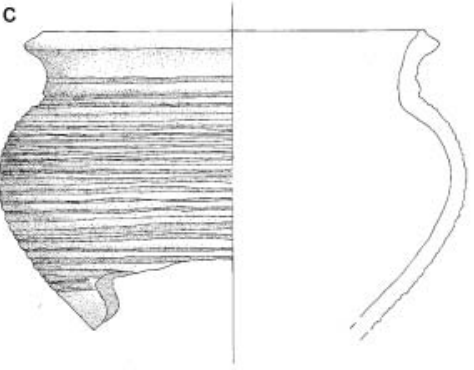

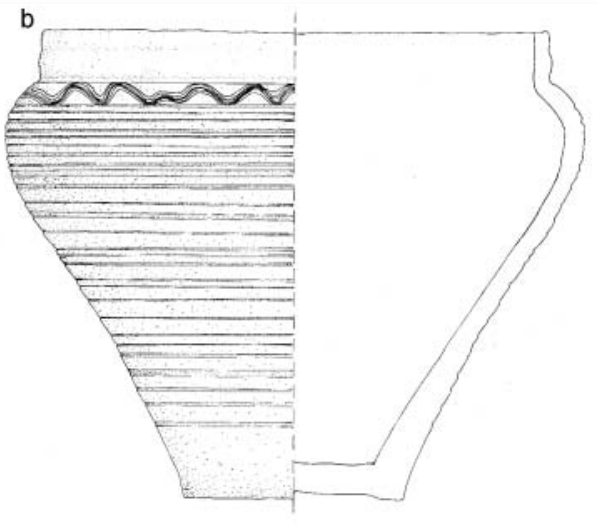

d

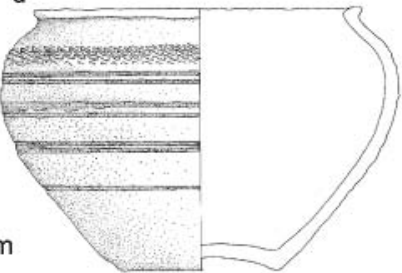

e

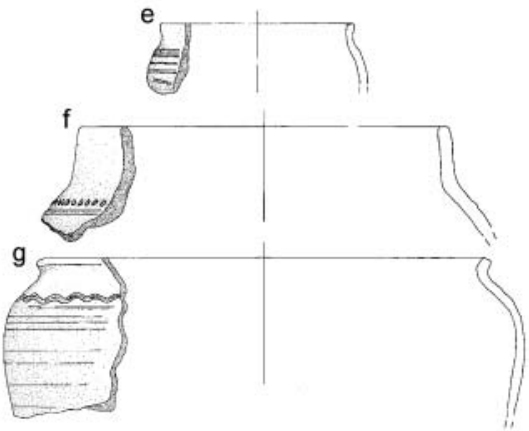

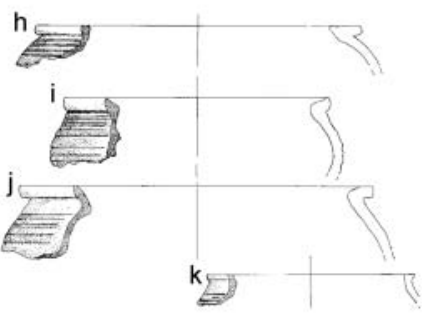

$0 \quad 5 \mathrm{~cm}$

Fig. 7. Pottery from feature 7 (a-k ) (drawing: A. Kroczyńska) 

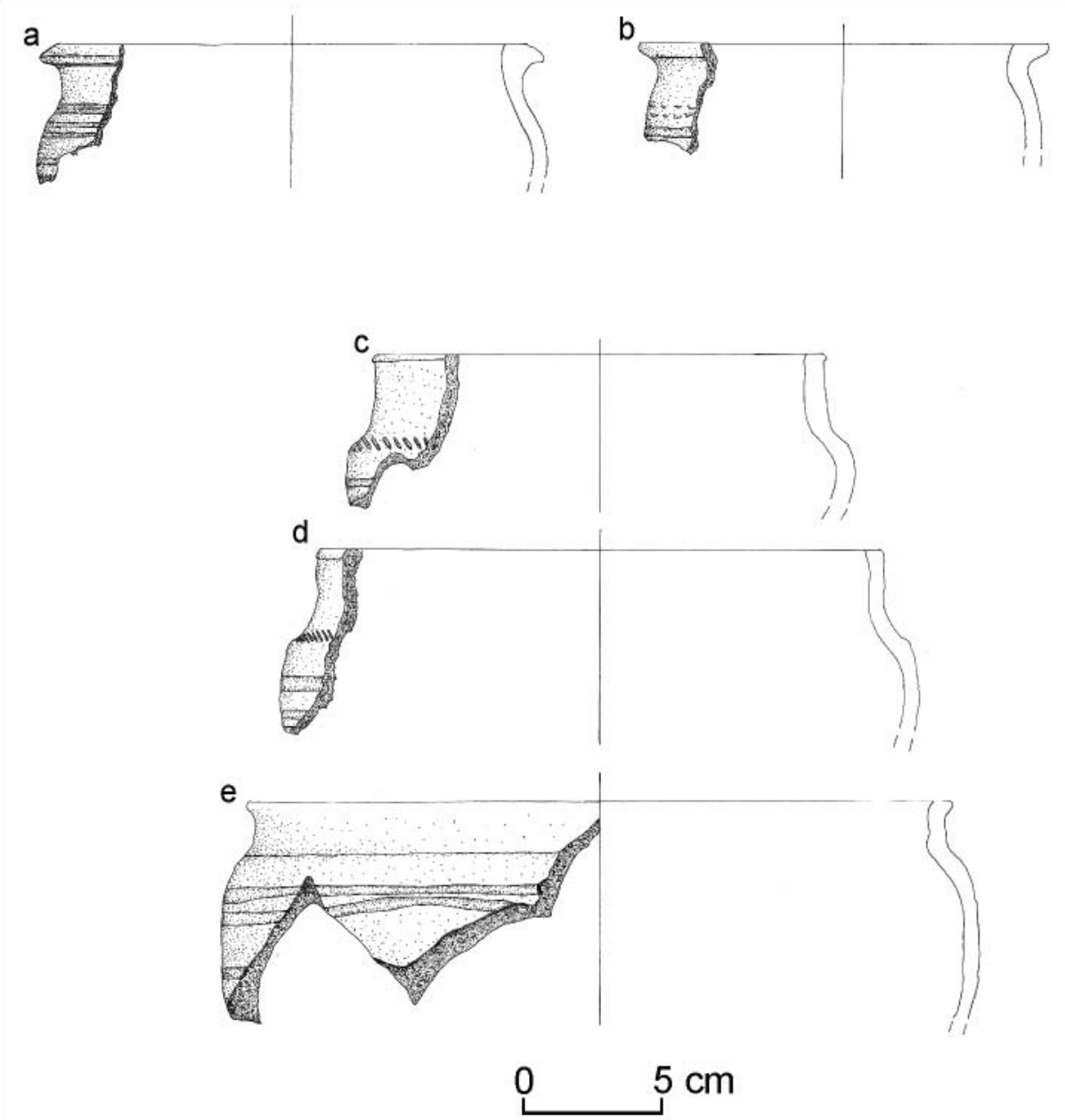

Fig. 8. Pottery from feature 1 (a-e) (drawing: A. Kroczyńska)

double horizontal grooves, one single groove, and multiplied corrugated lines placed in the upper part of the body. The assemblage of type $\mathrm{G}$ also includes 13 other sherds from the same feature (Fig. $7 \mathrm{~g}-\mathrm{k}$ ).

Another type of vessel recognised among the pottery recovered in feature 7 (Fig. 7b) is type $\mathrm{K}$ in the classification of pottery from Szczecin, not distinguished in the Mecklenburg's typology (Łosiński and Rogosz 1983, 217). Forms with a cylindrical neck are dated from the second half of eleventh century AD (Łosiński and Rogosz 1986, 56); although they are also recognised, in smaller numbers, among pottery from the beginning of the 
thirteenth century (Łosiński and Rogosz 1983, 235). The reconstructed vessel has an Sshaped outline with the diameter of $26 \mathrm{~cm}$ and height of $24 \mathrm{~cm}$. It is decorated in the upper part with a multiplied wavy line, below which there are horizontal grooves covering almost the entire height of the vessel. The K group also includes eight other sherds from the same feature (Fig. 7e-f). In addition, a sherd of the M/Bobzin type vessel (Łosiński and Rogosz 1983, 219-220) was also discovered in this feature, as well as six other sherds which were too small to be included in a specific taxonomic group. A similar technological-morphological division is visible in the sets of pottery coming from other features, where entirely wheel-made vessels prevail (technological group V), belonging to the abovementioned types $\mathrm{G}$ and $\mathrm{J}$.

Among the 56 potsherds which were retained from feature 1, 51 were early medieval, four prehistoric (early Iron Age), and one late medieval. In the early medieval group, seven fragments were classified as type G/Vipperow (Fig. 8a, b, e), three as K type (Fig. 8c, d), two fragments belonged to partially wheel-finished vessels (technological group III), and one fragment remained unidentified. In addition, 37 body sherds (GT V) and three base fragments were recovered from this feature.

In feature 2, the excavations yielded nine early medieval potsherds; including one base sherd and four fragments of vessel type J/Teterow (Fig. 9a, d-g), three fragments of vessel types G/Vipperow (Fig. 9b, c), and one of type K. In feature 3, 88 fragments of pottery were discovered. Among the group of 13 fragments of rims, seven belonged to type J/Teterow, three to type G/Vipper, two to the K type, and one to type M/Bobzin. In addition, in feature 3 there were 64 fragments of completely wheel-finished pottery (technological group V). In the assemblage ten base sherds were found, including one with a trace of the potter's wheel axis and one with a poorly visible trace of a maker's mark. There was also one fragment of a lid. Finally, feature 4 was the last feature from which pottery was obtained: it included five body sherds of completely wheel-finished vessels. Three sherds from that feature were dated to the early Iron Age.

To sum up the pottery analysis, the largest portion of the discussed assemblage comprises sherds of type G, 26 rim sherds and one fully reconstructed vessel. Next in number are type J: 15 rim sherds and two fully reconstructed vessels; and type K: 14 rim sherds and one fully reconstructed vessel. In addition to these types, two fragments of the $\mathrm{M}$ type vessels - including one fragment of a lid - were also found. Unfortunately, seven fragments of rims were too small to be assigned to any of the abovementioned groups. In terms of technology, wheel-finished vessels clearly dominate (technological group V), amounting to 81 percent of the assemblage. Other types were rare; partially wheel-finished sherds make up 3.2 percent of the assemblage (technological group III), uncharacteristic early medieval sherds 5.7 percent, and the early Iron Age sherds 10.1 percent of total. This kind of composition with the predominance sherds of types $\mathrm{G}, \mathrm{J}$ and $\mathrm{K}$, suggest that the assemblage, thus the whole discussed early medieval settlement, can be dated to the second half of the eleventh century. This morphological group of vessels corresponds to the IV chronological 

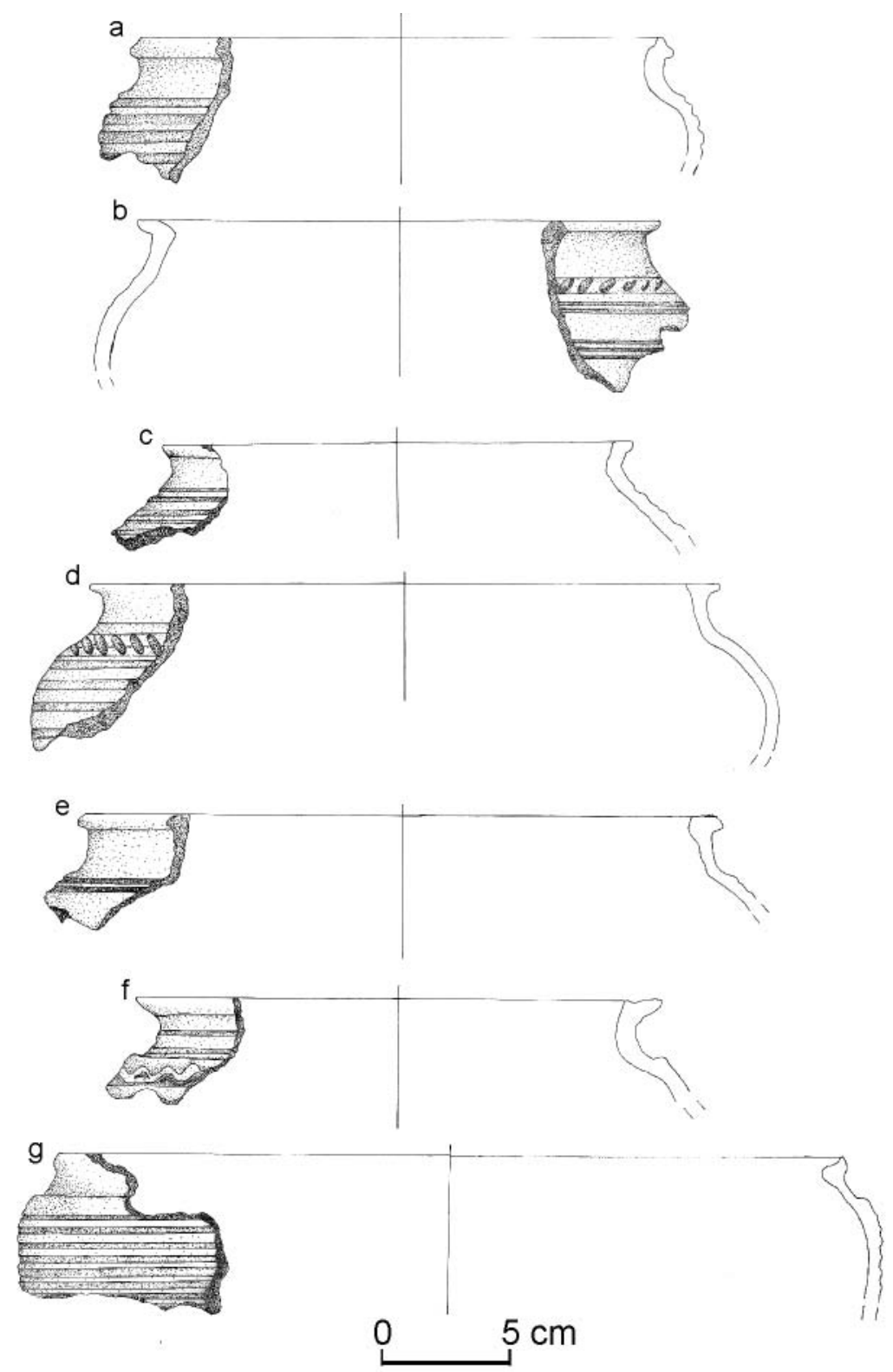

Fig. 9. Pottery from feature 2 (a-g) (drawing: A. Kroczyńska) 
horizon prepared for materials from Wolin dated from the half of eleventh century to the end of twelfth century AD (Stanisławski 2012, 107-108). The early Iron Age potsherds are probably intrusive and infiltrated the medieval deposits during the partial destruction of the Pomeranian culture burials by the early medieval structures. This statement is backed by the presence of a few flint flakes, made of Pomeranian (Baltic) flint, in features 4 and 6. According to Dr M. Wąs from the Institute of Archaeology and Ethnology of the University of Gdańsk, this type of artefact should rather be associated with the early Iron Age or the Bronze Age.

\section{Animal remains}

Two archaeological features, 3 and 7, yielded animal bones. Bone preservation was very poor in general; post-burial - or diagenetic - taphonomic factors altered bone tissue making it 'chalky' in appearance and very susceptible to damage (see: Cronyn 2004, 278). The vast majority of specimens broke into small pieces during post-ex handling, and their analysis was possible only based on the photographic record produced after the excavation. The paucity of remains hindered the quantitative analysis of taphonomy (Lyman 1994), osteometry (Albarella 2002), and paleoeconomy at the site (O'Connor 2003). The presence of severe post-burial taphonomic conditions suggests that the vast majority of bones perished in situ and the excavated assemblage is only a minuscule portion of the deposited one.

Only one identifiable bone was recovered from feature 3. It was a left tibia shaft fragment of sheep or goat (Ovis aries/Capra hircus). Its preservation was slightly better than other bones from Szemud, probably due to the fact that the specimen was charred (see Johnson 1989, 44). Strong heat causes bone tissue to lose its organic fraction, which is susceptible to some forms of taphonomic damage (Cronyn 2004, 277). Charring was presumably done after burial due to the proximity of a fireplace in the feature.

Feature 7 yielded two mandibles - of horse (Equus caballus) and cattle (Bos taurus) - as well as a femur shaft fragment of the horse. Unfortunately, all specimens, bone and teeth alike, crumbled into small pieces during transportation and handling, but the photographic evidence allowed the basic identification of the horse mandible. The specimen included premolars $\mathrm{PM}_{2}, \mathrm{PM}_{3}, \mathrm{PM}_{4}$ from both body sides. The in situ pictures (Fig. 10: d) suggest that both sides of the mandible held together in roughly anatomical position. The incisor area was broken off by post-burial taphonomic factors, leaving only both sides of the body of the mandible pressed and stuck together with soil. Based on the photographic record, the wear of the fourth premolar suggests that the individual reached adulthood (Silver 1969).

The remains of cattle and sheep/goat, common livestock, are presumably remnants of food waste. The presence of horse remains is potentially more interesting. At other early medieval sites in northern Poland, horse bones are scarce in comparison to those of ruminants and pigs. Usually they constitute up to a few percent of the assemblage; for example, 
from sites at Łącko (Makowiecki 1986), Lembarg (Makowiecki 1989a), Szczuk (Makowiecki 1992), Jedwabno (Makowiecki 1994), Gniezno (Makowiecki and Sobociński 1994), Gdańsk (Makowiecki and Makowiecka 2013), Stargard-Osetno (Makowiecka and Makowiecki 2014). At Bobrowa, horse was entirely absent (Makowiecki 1989b). On the other hand, horses - much more frequently than ruminants or pigs - are found as articulated skeletons or bone groups; for example, at Ostrów Lednicki (Makowiecki and Makowiecka 2014a). The paucity of horse remains in kitchen and household refuse is due to the low importance of horse meat compared to the importance of those animals for the early medieval societies (Makowiecki and Makowiecka 2014b, 358). Horses had tremendous utilitarian and economic value, and - whilst it is evidenced that they were consumed - its bones were often deposited in contexts of symbolic significance (Makowiecki and Makowiecka 2014b, 364-6).

\section{Small finds}

Almost all of the small finds were discovered in features 3, 4 and 7; only one was recovered from outside of them. Definitely the most interesting due to the context of its discovery was the almost unique element of this set of items: a surprisingly well preserved silver cross-shaped earring [Polish: zausznica krzyżowata] retained from feature 7 (Fig. 10c; 11a, b). These ornaments - termed 'openwork cross-shaped earrings' in the older archaeological literature (Kostrzewski 1962, 171) - have the form of a gemmed pendant in the shape of an equal-armed cross affixed to a semi-circular bow. The most complete description of this category of ornaments was given by H. Kóčka-Krenz; according to her:

The bow [of this item], in the upper part is made of wire of circular section with the end straightened; in the bottom part it is flattened, with a twisted filigree appended, and its end is rolled into an eyelet. Attached to the bow there was a pendant, which middle part had the shape of a flattened cube encompassed with granulated pattern or covered with filigree loops. Four cylindrical openwork arms are mounted to this part; each closed by half of a basket-shaped bead, and topped with a granule on a filigree cone. Through the base of one of these cones the bow of the earring is drawn. To its sides further openwork beads are attached, ending the bottom, flattened section of the bow (Kóčka-Krenz 1993, 80, translation form Polish).

The specimen from Szemud corresponds perfectly to this description. The almost entirely preserved cross-shaped pendant, with dimensions of about 44 x $44 \mathrm{~mm}$, was made very carefully. The bow is only partially preserved: the remains of the basket-shaped beads and the filigree wire, which was originally binding the bow, were damaged. Four arms were soldered to the flattened cube, which originally was encrusted with filigree (?) and decorated on the outside with a hollow knob. The underside of the cube bears traces of soldering and connecting of the arms of the cross to the cube. The arms have the form of openwork 
rolls, topped with halves of basket-shaped beads decorated with filigree cones, but only three pinnacles of the cross' arms were preserved. It is also worth noting that on the upper arm of the cross, in the place of connection with the bow, a small fragment of linen fabric was detected. Unfortunately, due to its poor state of preservation, the type of weave could not be determined. However, based on the current state of knowledge in this area, it was most likely linen weave (Maik 2015, 54).

The cross-shaped earring was not the only interesting artefact discovered at this site. In feature 7, apart from the pottery sherds described above, half of a turned amber bead was also recovered (Fig. 11: e). The bead had the diameter of $18 \mathrm{~mm}$ and the hole of $4 \mathrm{~mm}$, it was made on a lathe, and is decorated only with partially preserved circumferential grooves. Similar specimens of this kind are known from Gdańsk (Wapińska 1967, 90-91) or Wolin (Wojtasik 2013, 238-239), and are regarded as relatively common findings in the Baltic Sea region.

Another group of artefacts were made of iron. The first one is a half of the belt buckle from feature 4 with a D-shaped form and size $41 \times 27 \mathrm{~mm}$ (Fig. 11: c). This item could be originally used to strap a belt about $4 \mathrm{~cm}$ wide. Similar finds are known, among others, from Cedynia, Gryfino district (Malinowska-Łazarczyk 1979, 103) or Kałdus (Drozd 2006, 82), and are dated to a quite broad time frame from the mid-eleventh to the sixteenth century AD (Heindel 1990, 15). In this case, the specimen from Szemud should belong to the earliest horizon of those buckles. The last three iron items are difficult to identify unequivocally. The first artefact, discovered in feature 4, can be described as a fragment of a quadrilateral rod with an end rolled in an eyelet (size $17 \times 6 \mathrm{~mm}$, Fig. 11d). The second item, recovered from feature 3 , may be a fragment of a knife tang with a V-shaped section (size $33 \times 6 \mathrm{~mm}$, Fig. 11f). The last artefact is an unidentified piece of iron (dimensions: $30 \times 9 \mathrm{~mm}$, Fig. 11g) which was discovered during the exploration of Trench II without any direct relation to any of the features. Besides that, a clay spindle whorl with the diameter of $35 \mathrm{~mm}$ was acquired from feature 3 (Fig. 11).

\section{DISCUSSION}

One of the most unusual characteristics of the site at Szemud is the presence of a rare find of the cross-shaped earring in a unique context. The closest analogy for the find seems to be two items, almost entirely preserved, and derived from the hoard of silver jewellery from Bytów, district Bytów (Łęga 1930, 159; Kiersnowscy 1959, 34-35, fig.11i; Horoszko, Piniński, Ilisch, Malarczyk and Nowakiewicz 2016, 315, Taf. XVII. 21: 12-13). In these publications these artefacts are referred to as encolpions; on the other hand, in the study by Eggers $(1978,84)$ they are described as ' 2 silberne Filigranringe'. The next analogies come from Niederlandin, in present-day Germany (Landkreis Uckermark), where in a hoard of coins and silver decorations two nearly complete examples were discovered (Kiersnowscy 
1959, 75; Seyer 1997, 27 abb. 18, fig. 11: j). Another pendant of that type is known from Poznań and is linked with the so-called treasure "Poznań I" (Ślaski and Tabaczyński 1959, 50-51, tab. XVIII). Similar items - however, of a slightly different type due to different decoration of the arms - were found in solitary instances in hoards from Kretki, district Brodnica (Gloger 1901, 166, fig. 58; Gupieniec and Kiersnowscy 1965, 33), Ville, Skurups kommun in Sweden (Kostrzewski 1962, 171; Kóčka-Krenz 1982, 44, fig. 3.5), and finally from Ciechanów, district Płock, where:

Three large early medieval encolpions were discovered in the hoard. These are neck or breast decorations, made of thin silver wire, in the form of equal-armed crosses, which have on their top a thick, silver arched wire for hanging. Among three of those items deriving from this hoard, two are lacking one arm, and the third one consists only of the upper arm with the bail. (Gumowski 1905, 369, translation from Polish)

Unfortunately, there are no pictures or drawings of these artefacts (Gupieniec and Kiersnowscy 1965, 18).

Other examples of these items were described by Kostrzewski $(1962,171)$ and KóčkaKrenz (1992, 228). Unfortunately, they were preserved only in fragments, sometimes so small that they are difficult to interpret unambiguously. The fragment from the hoard dis-

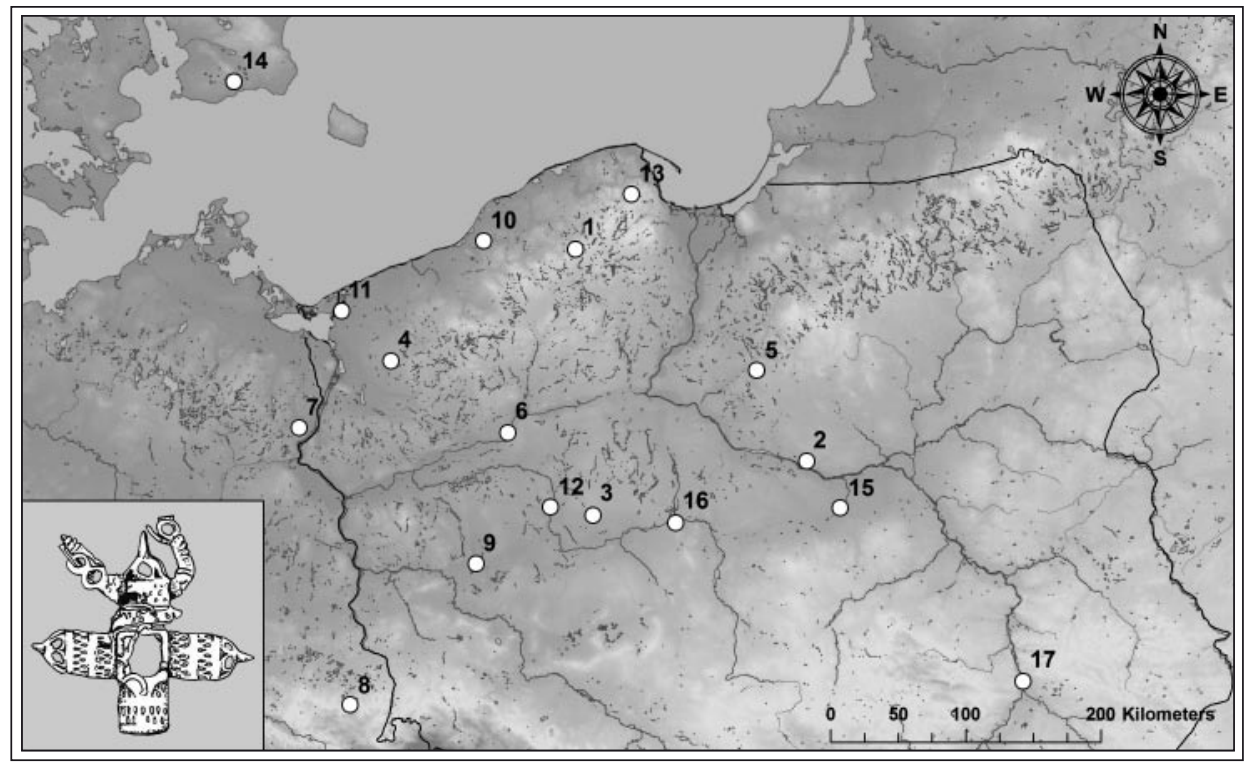

Fig. 12. Map of the dispersion of cross-shaped earrings from Pomerania and neighbouring areas. The numbers on the map correspond to the numbers in the catalogue at the end of the article (author: K. Niedziółka) 
covered at Obra Nowa (current name: Nowa Obra), Wolsztyn district, which may be considered analogous to the example from Szemud, was misidentified as originating from Trójca, Opatów district (see: Różańska 1960; Kostrzewski 1962, 171; Kóčka-Krenz 1993, 228). However, after a careful analysis of the figures in Różańska (1960, Tab. XI), as well as figures in Ślaski and Tabaczyński (1959, Tab. XIV), it may be assumed that those artefacts came from the same hoard. Besides that, an unspecified fragment of an earring was supposed to come from the hoard discovered at Pękanino, Sławno district (Kiersnowscy 1959, 79-80). In addition, at Piaski Wielkie - Dramino, Kamień Pomorski district (Kiersnowscy 1959, 79-80), according to Kóčka-Krenz (1993, 228), 22 fragments of these items were discovered; although, the analysis of the pictures taken from Schumann (1902, taf. V-VIII) requires caution regarding this number. The next examples of cross-shaped earrings are known from Kania, Stargard district (one item); Kuźnica Czarnkowska, CzarnkówTrzcianka district (one item); Zalesie, Konin district (one item); Dzierżnica, Środa Wielkopolska district (three items); Zakrzew I, Sochaczew district (one item); and Meschwitz, Landkreis Bautzen (one item) (Kóčka-Krenz 1993, 80, 228).

It seems that the current corpus of cross-shaped earrings should be somewhat revised. Currently, from the north-western Slavic area, there are only ten examples of completely preserved or slightly damaged items of this kind, and one other example from Sweden, and subsequent 32 more-or-less well identified fragments (see: Catalogue, Fig. 12). It is also extremely important that all of those examples - with the exception of the artefact from Szemud - derive from hoards, dated to the period from the mid-tenth to the mid-eleventh century AD (Kóčka-Krenz 1997, 70).

The uniqueness of the example of the cross-shaped earring from Szemud is linked to the context of the discovery. This item was probably revealed directly under the wooden floor (?) of a house in the place where the supposed fireplace was located. A second interesting artefact was found on same level of exploration: the horse mandible. The symbolic significance of the horse during the discussed period has been given a lot of attention in the archaeological literature (see: Makowiecki and Makowiecka 2014b, 362-6 for further literature). There are known cases of presumed horse sacrifices from Polish early medieval sites; at Kałdus, Chełmno district (Chudziak 2003, Makowiecki and Sobociński 2010); Żółte, Drawsko Pomorskie district (Makowiecki and Makowiecka 2014b, 362-366); or Poganowo, Kętrzyn district (Wyczółkowski and Makowiecki 2009). Horse skulls were interpreted as votive offerings (see: Rajewski 1975) and foundation sacrifices; for example, the sites at Czersk, Chojnice district (Hilczer-Kurnatowska 1982, 53), Gdańsk (Lepówna 1981, 178-185), Opole-Ostrówek, Opole district (Bukowska-Gedigowa and Gediga 1986, 213) or Wolin, Kamień Pomorski district (Filipowiak 1979, 117). In some cases, findings of this type were accompanied by everyday objects (Rajewski 1975); for example, at the site on the island in Żółte Lake, where the horse skull was found with a sheep skull in the immediate vicinity of a sickle and a ceramic vessel (Chudziak et al. 2007; Makowiecki and Makowiecka 2014b, 340). 
It is possible that the cross-shaped earring deposited together with a part of the head of a horse constitutes a special offering for a newly built house or hearth. It should be mentioned, however, that in feature 7 no other fragments of horse skull were found, and the mandible itself may be a remnant of other, possibly more utilitarian, activities or be intrusive to this archaeological context.

When it comes to using artefacts akin to the cross-shaped earring as apotropaic items, it is worth mentioning the finding of an amber cross together with a so-called Thor's Hammer discovered at the early medieval site in the outer bailey in Gdańsk, near house 76 (Lepówna 1981, 178). This discovery is associated with the eighth level of settlement dated to the second quarter of the twelfth century AD (Barnycz-Gupieniec 2005, 10). Perhaps the case of the Szemud silver cross-shaped earring and the fragment of horse skull - which were possibly supposed to protect the hearth, the building and its inhabitants - should be interpreted in the same way as the findings from Gdańsk (see Wawrzeniuk 2016, 49-62 for further literature). Furthermore, there is still an open question of the connection between this type of jewellery and the Christian sphere of the sacred. It should be remembered that they are not necessarily only head ornaments, and could also been worn on the breast as a particular form of sacred encolpion. Therefore, it is possible that the placing of such a valuable item in a foundation sacrifice constituted an attempt to give it a new symbolic value derived from the sphere of pre-Christian religiosity.

The discovery of this kind of artefact in the context of a structure interpreted as a residential building should not, however, imply its uniqueness. We may be dealing here with archaeological material constituting yet another example of the Slavic building construction ritual (Bajburin 1990).

\section{CONCLUSIONS}

The findings from Szemud presented in this paper are an important contribution to the research of early medieval settlement in Eastern Pomerania for several reasons. Firstly, the silver cross-shaped earring recovered at the site is an unusual find in itself. The artefacts of this kind are known, so far, only from the hoards, and a context of the settlement at which this discovery was made is unusual; especially, considering the essential homogeneity of material culture of the early medieval rural settlements, which underwent only minor changes over the centuries (Buko 2011, 323-325). Besides this particularly interesting item, the excavations yielded a relatively large number of potsherds constituting a relatively consistent assemblage providing a precise dating of the settlement. This information is very valuable, taking into consideration that these kinds of settlements generally have a very broad dating.

Unfortunately, not much is known about the layout of this settlement, its size and character, except that it was an open settlement without any fortifications, at least in the range 
of the excavated area. It is possible that the site was a part of a larger settlement with dense habitation; on the other hand, it could also be a remnant of a single homestead being a part of a more dispersed settlement system. The research from 2014 on the early Iron Age cemetery in Trench I (Fig. 1: b) have not detected the continuation of the early medieval settlement south of the discussed site. This may imply that the excavated site formed the southern border of a medieval settlement which was located on the place of the early Iron Age cemetery, partially destroying it. What is more, it is possible that the analysed medieval settlement was wider and extended further north. Unfortunately, because of the modern infrastructure in that area, this hypothesis cannot be verified at present.

In conclusion, it seems that the structures and features uncovered and finds retained in the course of excavations at site 4 at Szemud, although relatively scarce, can significantly enrich the contemporary knowledge of the early Middle Ages in this part of Eastern Pomerania.

\section{Acknowledgements}

The part of this text, concerning the analysis of early medieval finds, was prepared due to the generous support of the National Science Center Poland, which funded project entitled „Religie i ich rzeczy. Analiza porównawcza wczesnośredniowiecznych przedmiotów związanych z religijnością odkrytych na terenie Polski” (DEC-2017/24/C/HS3/oo116) led by Paweł Szczepanik.

\section{The catalogue of cross-shaped earrings from Central and Northern Europe (list prepared by P. Szczepanik)}

1. Bytów, Bytów com., Bytów distr., Poland (Kiersnowscy 1959, 34-35): 2 complete items

2. Cekanowo, Słupno com., Płock distr., Poland (Gupieniec and Kiersnowscy 1965, 18): 3 items made of silver

3. Dzierznica II, Dominowo com., Środa Wielkopolska distr., Poland (Śląski and Tabaczyński 1959, 19-20): 3 fragments made of silver

4. Kania, Chociwel com., Stargard distr., Poland (Kierscowscy 1959, 55): 1 fragment

5. Kretki, Osiek com., Brodnica distr., Poland (Gloger 1901; Gupieniec and Kiersnowscy 1965, 33): 1 item made of silver

6. Kuźnica Czarnkowska, Czarnków com., Czarnków distr., Poland (Koćka-Krenz 1993, 228): 1 fragment

7. Niederlandin, Landkreis Uckermark, Germany (Kiersnowscy 1959, 74-75; Corpus 1979 b, 14-16): 2 item

8. Meschwitz, Landkreis Bautzen, Germany (Dutschmann 1926; Kiersnowski 1964, 48; Corpus 1985, 148-149): 1 fragment 
9. Nowa Obra, Wolsztyn com., Wolsztyn distr., Poland (Ślaski and Tabaczyński 1959, 44-45): 2 items

10. Pękanino, Malechowo com., Sławno distr., Poland (Kiersnowscy 1959, 79-80): 1 fragment made of silver

11. Piaski Wielkie-Dramino, Wolin com., Kamień Pomorski distr., Poland (Schuman 1900; Kiersnowscy 1959, 80-81): 22 fragments [sic!] made of silver

12. Poznań I, Poland (Ślaski and Tabaczyński 1959, 50-51): 1 item.

13. Szemud, Szemud com., Wejherowo distr.: 1 item made of silver

14. Villie, Skurups kommun, Sweden (Kóčka-Krenz 1982, 46): 1 item

15. Zakrzew I, Nowa Sucha com., Sochaczew distr., Poland (Gupieniec and Kiersnowscy 1965, 61): 1 fragment

16. Zalesie, Krzymów com., Konin distr., Poland (Ślaski, Tabaczyński 1959, 72; Dekówna 1974): 1 fragment

17. Zawichost (formerly a separate village called Trójca), Zawichost com., Sandomierz distr., Poland (Różańska 1960; Haisig et al. 1966, 26): 2 fragmented items made of silver

\section{References}

Adamska E. 2005. Osada wczesnośredniowieczna w Maleninie, gmina Tczew, stanowisko 5 (153 na A1). In H. Paner and M. Fudziński (eds.), XIV Sesja Pomorzoznawcza 2. Gdańsk: Muzeum Archeologiczne, 171-180.

Albarella U. 2002. Size matters: how and why biometry is still important in zooarchaeology. In K. Dobney and T. O'Connor (eds.), Bones and the Man: Studies in honour of Don Brothwell. Oxford: Oxbow Books, 51-62.

Bajburin A. 1990. W sprawie struktury słowiańskiego rytuału budowniczego. Polska Sztuka Ludowa: Konteksty 44(3), 62-67.

Barnycz-Gupieniec R. 2005. Planigrafia materiału zabytkowego z osady podgrodowej wczesnośredniowiecznego Gdańska (stanowisko 1). Gdańsk: Muzeum Archeologiczne w Gdańsku.

Bednarczyk J. 2003. Ratownicze badania wykopaliskowe osady wielokulturowej w Juszkowie - Rusocinie, stanowisko 28, województwo pomorskie. In M. Fudziński and H. Paner (eds.), XIII Sesja Pomorzoznawcza 1. Gdańsk: Muzeum Archeologiczne, 191-199.

Bielska A., Kwiatkowska-Malina J., Maciejewska A., Skłodowski P. and Szafranek A. 2014. Podstawy gleboznawstwa z elementami kartografii gleb. Warszawa: Oficyna Wydawnicza Politechniki Warszawskiej.

Błędowski P., Chudziak W. 2014. Pottery. In W. Chudziak and R. Kaźmierczak (eds.), The Island in Żótte on Lake Zarańskie. Early Medieval Gateway into West Pomorania. Toruń: Nicolaus Copernicus University, 111-145.

Buko A. 2011. Archeologia Polski wczesnośredniowiecznej. Warszawa: TRIO.

Bukowska-Gedigowa J. and Gediga B. 1986. Wczesnośredniowieczny gród na Ostrówku w Opolu. Wrocław: Zakład Narodowy im. Ossolińskich. 
Brzostowicz M. 2014. Stan i potrzeby badań nad konstrukcjami drewnianymi pochodzącymi z grodzisk wczesnośredniowiecznych w Polsce. In A. Stempin and W. Olek (eds.), Dąb wczesnośredniowieczny - zapis poznania. Badania nad zabezpieczeniem i ochrona konstrukcji wałów grodowych eksplorowanych $w$ Rezerwacie Archeologicznym Genius loci na Ostrowie Tumskim $w$ Poznaniu. Poznań: Wydawnictwo Uniwersytetu Przyrodniczego, 49-84.

Choińska E. 1975. Stan i potrzeby badań archeologicznych nad osadnictwem na zachodnim brzegu Dolnej Wisły we wczesnym średniowieczu. Pomorania Antiqua 6, 151-191.

Chudziak W. 1987. Z badań nad budownictwem drewnianym Wielkopolski w okresie wczesnego średniowiecza. Sprawozdania Archeologiczne 39, 343-346.

Chudziak W. 1988. Z badań nad konstrukcją zrębową na Niżu Polskim we wczesnym średniowieczu. Slavia Antiqua 31, 183-198.

Chudziak W. 2003. Wczesnośredniowieczna przestrzeń sakralna in Culmine na Pomorzu Nadwiślańskim (= Mons Sancti Laurentii 1). Toruń: Wydawnictwo Naukowe Uniwersytetu Mikołaja Kopernika.

Chudziak W. 2006. Stan i potrzeby badań nad wczesnym średniowieczem Pomorza Nadwislańskiego. In W. Chudziak and S. Moździoch (eds.), Stan i potrzeby badań nad wczesnym średniowieczem w Polsce - 15 lat później. Torun, Wrocław, Warszawa: Wydawnictwo UMK, 175-187.

Chudziak W., Kaźmierczak R. and Niegowski J. 2007. Z badań nad wczesnośredniowiecznym zespołem osadniczym w Żółtym, gm. Drawsko pomorskie (lata 2004-2005). In G. Nawrolska (ed.), XV Sesja Pomorzoznawcza. Elbląg: Muzeum Archeologiczno-Historyczne w Elblągu, 231-248.

Chudziak W., Poliński D. and Moszczyński W. 1997. Schemat analizy opisowej wczesnośredniowiecznej ceramiki naczyniowej. In W. Chudziak (ed.), Wczesnośredniowieczny szlak lądowy z Kujaw do Prus (XI wiek). Studia i materiaty (= Adalbertus 2). Toruń: Uniwersytet Mikołaja Kopernika, 231-243.

Dobrogowski T. 1949. Dwa cmentarzyska kultury pomorskiej w Szemudzie, pow. pomorski. Przegląd Archeologiczny 8(2), 299-314.

Drozd A. 2006. Biżuteria i części stroju. In W. Chudziak (ed.), Wczesnośredniowieczne cmentarzysko szkieletowe w Kałdusie (stanowisko 1) (= Mons Sancti Laurentii 3), Toruń: Uniwersytet Mikołaja Kopernika, 67-84.

Drwal J. 1979. Charakterystyka hydrograficzna. In B. Augustowski (ed.) Pojezierze Kaszubskie. Gdańsk: GTN, 121-138.

Dulinicz M. 2001. Ksztaltowanie się Stowiańszczyzny Pótnocno-Zachodniej. Studium archeologiczne. Warszawa: Instytut Archeologii i Etnologii PAN.

Eggers H. J. 1978. Funde der Wendisch-Wikingischen Zeit in Pommern Textband. Kiel: Stiftung Pommern.

Filipowiak W. 1979. Wolińska kącina. Z Otchłani Wieków 45(2), 108-121.

Fudziński P., Fudziński M. and Adamska E. 2007. Wielokulturowa osada w Ulkowych, gm. Pszczółki, stanowisko 24 (na trasie autostrady A1). In G. Nawrolska (ed.), XV Sesja Pomorzoznawcza. Elbląg: Muzeum Archeologiczno-Historyczne w Elblągu, 69-80. 
Gacki T. and Szukalski J. 1979. Zróżnicowanie geoekologiczne i regionalne oraz problemy antropizacji i ochrony środowiska geograficznego. In B. Augustowski (ed.), Pojezierze Kaszubskie. Gdańsk: GTN, 221-253.

Gloger Z. 1901. Wykopalisko w Kretkach. Światowit 3, 165-166.

Gupieniec A., Kiersnowscy T. and R. 1965. Wczesnośredniowieczne skarby srebrne z Polski Środkowej, Mazowsza i Podlasia. Materiaty (= Polskie Badania Archeologiczne 10). Warszawa, Wrocław: Zakład Narodowy im. Ossolińskich Wydawnictwo Polskiej Akademii Nauk.

Heindel I. 1990. Riemen- und Gürtelteile im westslawischen Siedlungsgebiet (= Beiträge zur Urund Frühgeschichte der Bezrike Rostock, Schwerin und Neubrandenburg 23). Berlin: Deutscher Verlag der Wissenschaften.

Hilczer-Kurnatowska Z. 1982. Zakładzina. In G. Labuda and Z. Stieber (eds.), Stownik Starożytności Stowiańskich 7. Wrocław: Zakład Narodowy im. Ossolińskich, 52-54.

Johnson E. 1989. Human modified bones from early southern Planis Sites. In R. Bonnichsen and M. H. Sorg (eds.), Bone modification. Orono: University of Maine Centre for the Study of the First Americans, 431-471.

Kiersnowscy T. and R. 1959. Wczesnośredniowieczne skarby srebrne z Pomorza. Materiaty (= Polskie Badania Archeologiczne 4). Warszawa, Wrocław: Zakład Narodowy im. Ossolińskich Wydawnictwo Polskiej Akademii Nauk.

Kittel P. 2005. Uwarunkowania środowiskowe lokalizacji osadnictwa pradziejowego na Pojezierzu Kaszubskim i w pólnocnej części Borów Tucholskich. Łódź: Instytut Archeologii UŁ.

Kistowski M. and Szydłowski J. 2015. Zastosowanie GIS w delimitacji regionów fizycznogeograficznych w kontekście wdrażania Europejskiej Konwencji Krajobrazowej. Problemy Ekologii Krajobrazu 40, 161-176.

Kobyliński Z. 1988. Struktury osadnicze na ziemiach polskich u schyłku starożytności i $w$ początkach wczesnego średniowiecza. Wrocław: Zakład Narodowy im. Ossolińskich.

Kondracki J. 2002. Geografia regionalna Polski. Warszawa: Wydawnictwo Naukowe PWN.

Kostrzewski J. 1962. O pochodzeniu ozdób srebrnych z polskich skarbów wczesnośredniowiecznych. Slavia Antiqua 9, 139-211.

Kóčka-Krenz H. 1982. Some aspects of Polish Early Medieval Matalworking. Fornvänen 77, 38-47.

Kóčka-Krenz H. 1993. Biżuteria pótnocno-zachodnio-stowiańska we wczesnym średniowieczu (= Seria Archeologia 40). Poznań: Uniwersytet im. Adama Mickiewicza w Poznaniu.

Kóčka-Krenz H. 1997. Biżuteria średniowieczna na ziemiach polskich jako wyznacznik chronologiczny. Archaeologia Historica Polona 6, 69-75.

Kruk J. and Przywara L. 1983. Roślinność potencjalna jako metoda rekonstrukcji naturalnych warunków rozwoju społeczności pradziejowych. Archeologia Polski 28(1), 19-50.

Lepówna B. 1981. Materialne przejawy wierzeń ludności Gdańska w X-XIII. Pomorania Antiqua 10, 169-199.

Lyman R. L. 1994. Vertebrate taphonomy. Cambridge: Cambridge University Press.

Łęga W. 1930. Kultura Pomorza we wczesnem średniowieczu na podstawie wykopalisk. Toruń: Towarzystwo Naukowe. 
Łosiński W. 1981. Aktualne problemy badań archeologicznych nad wczesnym średniowieczem Pomorza. Pomorania Antiqua 10, 131-154.

Łosiński W. and Rogosz R. 1983. Zasady klasyfikacji i schemat taksonomiczny ceramiki. In. E. Cnotliwy, L. Leciejewicz and W. Łosiński (eds.), Szczecin we wczesnym Średniowieczu. Wzgórze Zamkowe. Wrocław: Zakład Narodowy im. Ossolińskich, 202-225.

Łosiński W. and Rogosz R. 1986. Próba periodyzacji ceramiki wczesnośredniowiecznej ze Szczecina. In. J. Gromnicki (ed.), Problemy chronologii ceramiki wczesnośredniowiecznej na Pomorzu Zachodnim. Warszawa: Wydawnictwa PKZ, 9-50.

Maik J. 2015. Stan badań nad wczesnośredniowiecznym włókiennictwem pomorskim. Pomorania Antiqua 24, 47-62.

Makowiecki D. 1986. Szczątki kostne zwierząt z osady wczesnośredniowiecznej w Łącku. Roczniki Akademii Rolniczej w Poznaniu 172 Archeozoologia 11, 57-66.

Makowiecki D. 1989a. Materiał kostny zwierząt ze wczesnośredniowiecznego Lębargu, woj. toruńskie. Roczniki Akademii Rolniczej w Poznaniu 206 Archeozoologia 14, 27-40.

Makowiecki D. 1989b. Zwierzęce szczątki kostne z grodziska wczesnośredniowiecznego w Bobrowie, woj. toruńskie. Roczniki Akademii Rolniczej w Poznaniu 206 Archeozoologia 14, 41-50.

Makowiecki D. 1992. Zwierzęce szczątki kostne z grodziska wczesnośredniowiecznego w miejscowości Szczuka, gm. Brodnica. Roczniki Akademii Rolniczej w Poznaniu 237. Archeozoologia 17, 41-47.

Makowiecki D. 1994. Wyniki badań archeozoologicznych szczątków kostnych z wczesnośredniowiecznego grodziska (stanowisko 1) i osady (stanowisko 2) w Jedwabnie, województwo toruńskie. In W. Chudziak (ed.), Studia nad Osadnictwem Średniowiecznym Ziemi Chetmińskiej (= Studia i Materiały 2). Toruń: Wydawnictwo Uniwersytetu Mikołaja Kopernika, 187-217

Makowiecki D. and Makowiecka M. 2013. The character of animal exploitation and the environment at the Polish/Prussian frontier in the medieval period: a case study. Archaeologia Baltica 20, 91-116.

Makowiecki D. and Makowiecka M. 2014a. Zwierzęce szczątki kostne z podwodnych badań archeologicznych mostu „poznańskiego” w Rybitwach, stanowisko 3a. In A. Kola and G. Wilke (eds.), Wczesnośredniowieczne mosty przy Ostrowie Lednickim 2: Mosty traktu poznańskiego. Toruń: Universitas, 263-270.

Makowiecki D. and Makowiecka M. 2014b. Faunal remains. In W. Chudziak and R. Kaźmierczak (eds.), The Island in Żótte on Lake Zarańskie, Early Medieval Gateway into West Pomerania. Toruń: Institute of Archaeology, Nicolaus Copernicus University, 311-366.

Makowiecka M. and Makowiecki D. 2014. Wynik badań archeozoologicznych pozostałości zwierzęcych z badań wykopaliskowych w Stargardzie - Osetnie, stanowisko 1. Stargardia 9, 21-56.

Makowiecki D. and Sobociński M. 1994. Zwierzęcy materiał kostny z osady wczesnośredniowiecznej w Gnieźnie-Piotrowie (stanowisko 40). Roczniki Akademii Rolniczej w Poznaniu 259. Archeozoologia 19, 19-35.

Makowiecki D. and Sobociński M. 2010. Ocena archeozoologiczna depozytów szkieletowych konia (Equus ferus f. caballus) z Kałdusa. In D. Makowiecki (ed.), Wczesnośredniowieczna gospodarka 
zwierzętami i socjotopografia in Culmine na Pomorzu Nadwiślańskim (= Mons Sancti Laurentii 6), 307-311.

Malinowska-Łazarczyk H. 1979. Typologia i chronologia sprzączek i okuć pasa z cmentarzyska w Cedyni. Materialy Zachodniopomorskie 22, 111-121.

Marcinkowska A., Ochtyra A., Olędzki J. R., Wołk-Musiał E. and Zagajewski B. 2013. Mapa geomorfologiczna województw pomorskiego i warmińsko-mazurskiego z wykorzystaniem metod geoinformatycznych. Teledetekcja Środowiska 49, 43-79.

Matuszkiewicz J. M. 1993. Krajobrazy roślinne i regiony geobotaniczne Polski (= Prace Geograficzne 158). Warszawa: IGiPZ PAN.

Matuszkiewicz J. M. 2008. Potencjalna roślinność naturalna Polski. Warszawa, https://www.igipz. pan.pl/tl_files/igipz/ZGiK/opracowania/roslinnosc_potencjalna/prn_opracowanie.pdf, [accessed: 03.04.2017].

Niedziółka K. 2016. The prospect of digitization of Polish Archaeological Record on an example of materials from the turn of Bronze and Iron Age from the area of Pomeranian Voivodeship (Northern Poland). Sprawozdania Archeologiczne 68, 121-144.

Niedziółka K. and Jasińska M. 2017. Cmentarzysko z wczesnej epoki żelaza w Szemudzie, powiat wejherowski, stan. 3. Pomorania Antiqua 26 (in press).

Nierychlewska A. 2013. Archeologiczne badania ratownicze wczesnośredniowiecznej osady w Jankowie Gdańskim, gm. Kolbudy. In A. Fudzińska (ed.), XVIII Sesja Pomorzoznawcza 1. Malbork: Muzeum Zamkowe, 271-291.

O'Connor T. P. 2003. The Analysis of Urban Animal Bones Assemblages. A Handbook for Archaeologists. The Archaeology of York 19: Principles and Methods. York: York Archaeological Trust/Council for British Archaeology.

Ochtyra A., 2012. Mapa geomorfologiczna województwa pomorskiego. Warszawa: Katedra Geoinformatyki i Teledetekcji Wydziału Geografii i Studiów Regionalnych UW. Warszawa (unpublished).

Ostasz A. 2014. Nowe badania na grodziskach wczesnośredniowiecznych ziemi gdańskiej. In H. Paner, M. Fudziński and W. Świętosławski (eds.), Pomorze we wczesnym średniowieczu $w$ świetle źródet archeologicznych. Gdańsk: Muzeum Archeologiczne, 57-90.

Paner H, Fudziński M. and Świętosławski W. (eds.) 2014. Pomorze we wczesnym średniowieczu $w$ świetle źródet archeologicznych. Gdańsk: Muzeum Archeologiczne.

Pelisiak A. and Gębica P. 2007. Podstawy geomorfologii i gleboznawstwa dla archeologów. Rzeszów: Instytut Archeologii Uniwersytetu Rzeszowskiego.

Pietrzak M. 1977. Nowe odkrycia na Pomorzu Gdańskim. Pomorania Antiqua 7, 505-507.

Poklewski T. 1992. Sytuacja w badaniach archeologicznych wsi wczesnośredniowiecznej w Polsce. In Z. Kurnatowska (ed.), Stan i potrzeby badań nad wczesnym średniowieczem w Polsce. Poznań, Wrocław, Warszawa: PTPN, 297-298.

Rajewski, Z. 1975. Koń w wierzeniach u Słowian wczesnośredniowiecznych. Wiadomości Archeologiczne 39(4), 516-521. 
Różańska H. 1960. Wczesnośredniowieczny skarb srebrny z miejscowości Trójca pow. Opatów. Materiały Wczesnośredniowieczne 5, 261-282

Schuldt E. 1956. Die Slawische Keramik In Mecklenburg. Berlin: Akademie-Verlag.

Schumann H. 1902. Der Hacksilberfund von Paatzig (Kr. Camin). Baltische Studien. Neue Folge 6, 74-94.

Seyer H. 1997. Slawische Silberschatzfunde des Mittelalters aus der Prähistorischen Sammlung des Stadtmuseums Berlin. Berlin: Stiftung Stadtmuseum Berlin.

Silver I. 1969. The ageing of domestic animals. In D. Brothwell and E. Higgs (eds.), Science in Archaeology, 2nd ed. London: Thames and Hudson, 283-302.

Szymańska A. 1968. Nowe materiały na Pomorzu Gdański. Pomorania Antiqua 2, 371-372.

Ślaski J. and Tabaczyński S. 1959. Wczesnośredniowieczne skarby srebrne Wielkopolski. Materiaty (= Polskie Badania Archeologiczne 1). Warszawa, Wrocław: Zakład Narodowy im. Ossolińskich Wydawnictwo Polskiej Akademii Nauk.

Wapińska A. 1967. Materiały do wczesnośredniowiecznego bursztyniarstwa gdańskiego. In J. Kamińska (ed.), Gdańsk wczesnośredniowieczny 6. Gdańsk: Gdańskie Towarzystwo Naukowe, 83100.

Wawrzeniuk J. 2016. Magia ochronna Stowian we wczesnym średniowieczu na ziemiach polskich. Warszawa: Wydawnictwo Uniwersytetu Kardynała Stefana Wyszyńskiego.

Wojtasik J. 2013. Bursztyniarstwo wczesnośredniowiecznego Wolina. In B. Stanisławski and W. Filipowiak (eds.), Wolin wczesnośredniowieczny. Część 1 (= Origines Polonorum 6). Warszawa: Wydawnictwo Trio, 235-249.

Wyczółkowski M. and Makowiecki D. 2009. Horse sacrifices in Prussia in the Early Middle Ages. Ritual area in Poganowo site IV, Olsztyn province (Poland). In A. Bliujiene (ed.), The Horse and Man in European Antiquity (Worldview, Burial Rites, and Military and Everyday Life). Klaipeda: Klaipeda University Press, 295-304. 
